\title{
Impact of Microorganisms on Arsenic Biogeochemistry: A Review
}

\author{
Jen-How Huang
}

Received: 18 September 2013 / Accepted: 18 December 2013 /Published online: 18 January 2014

(C) Springer Science+Business Media Dordrecht 2014

\begin{abstract}
Microorganisms are abundant in many surface and near-surface geochemical environments. They interact with arsenic through a variety of mechanisms, including sorption, mobilisation, precipitation and redox and methylation transformation; sometimes, this is to their benefit, while other times it is to their detriment, substantially affecting the fate and transport of arsenic in the environment. Here, an attempt was made to review the current state of knowledge concerning microbial influences on arsenic transformation and retention processes at the water-solid interface with the goal to elucidate the ability of microorganisms to react with arsenic, and to quantify the role of microorganisms in the biogeochemical arsenic cycle. Such knowledge is indispensable for comprehensive understanding arsenic behaviour in the environment and support accurate assessment of the threat of arsenic contamination to human and environmental health, as well as for the development of novel technologies for arsenic bioremediation.
\end{abstract}

Keywords Arsenic $\cdot$ Microorganism .

Biogeochemistry $\cdot$ Redox transformation $\cdot$ Methylation

\section{Introduction}

Arsenic (As) is one of the most toxic elements and a non-threshold class 1 carcinogen (Vahidnia et al. 2007).

J.-H. Huang $(\bowtie)$

Environmental Geosciences, University of Basel,

4056 Basel, Switzerland

e-mail: jen-how.huang@unibas.ch
There is increasing evidence of cancer risk associated with chronic exposure of low levels of As (Cantor, 1996). Today, elevated As concentrations represent a major water quality and health problem for millions of people worldwide (Bundschuh et al. 2012; Nordstrom 2002; Smedley and Kinniburgh 2002). Naturally high concentrations of As in surface and ground waters may be due to geothermal sources or from the dissolution of As-bearing minerals in soils and sediments, whereas anthropogenic inputs result from emissions of mining and smelting activities (Bissen and Frimmel 2003; Fendorf et al. 2010a; Smedley and Kinniburgh 2002). In comparison, immobilisation of As in the environment occurs predominately by sequestration to soil and sediment solid phases (Fendorf et al. 2010b; Smedley and Kinniburgh 2002).

Although the possibility of a "new As form of life" is highly controversial, the significance of As in life science has drawn much public attention (Parke 2013; Wolfe-Simon et al. 2011). Microorganisms constitute the majority of all living matter on Earth (Toner et al. 2006) and, as such, form a foundational component of the entirety of Earth's environment, along with the lithosphere, soils, oceans and the atmosphere. Microorganisms play a major role in driving, along with the inanimate Earth, biogeochemical cycles, which involve the most fundamental underlying aspects of our entire environment, namely electron and elemental transfer among all of the compartments of the Earth's environmental systems (Tamaki and Frankenberger, 1992). The result is the unmistakable influence of microorganisms on, for example nitrogen and carbon cycling, mineral growth and dissolution, biological nutrient fluxes, and on a larger scale, ocean and atmospheric chemistry. 
Modification of microbial composition and activity can have consequences on local, regional and global scales.

The fate of As released into geochemical environments is determined by a complex interplay among processes of As mobilisation, sequestration and transformation, most of which are directly or indirectly driven by microbial activity. There are already plenty of researches focussing on understanding the behaviour of As in different compartments of the surface and subsurface environment (see review articles, e.g. Cullen and Reimer 1989; Mandal and Suzuki 2002; Smedley and Kinniburgh 2002). On the other hand, many efforts were focussed on characterising the ability of microorganism to interact with As, e.g. respiratory oxidation and reduction and methylation, and the corresponding physiological mechanisms (see review articles e.g. Dhuldhaj et al. 2013; Lloyd and Oremland 2006; Mukhopadhyay et al. 2002; PaezEspino et al. 2009; Silver and Phung 2005; Slyemi and Bonnefoy 2012; Tsai et al. 2009). Studies on microbial diversity in natural samples to estimate As behaviour are also abundant (e.g. Fan et al. 2008; Meyer-Dombard et al. 2013; Tomczyk-Żak et al. 2013). However, comparably few studies have been aimed at truly understanding the linkage between microbial activities and As geochemistry in the environment, especially for the natural system. These studies were achieved by investigating As geochemistry in parallel with microbiology and molecule ecology in more depth instead of only comparing the sterile control or just adding organic substances to stimulate certain microbial activities, thereby enabling identification of the link between microorganisms and As geochemistry with strong evidence. For example, Islam et al. (2004) showed that As release from the sediments of West Bengal delta occurred along with $\mathrm{Fe}(\mathrm{III})$ and arsenate $(\mathrm{As}(\mathrm{V}))$ reduction in the presence of Clostridium species (involved in $\mathrm{As}(\mathrm{V})$ reduction), and Geobacter species (involved in $\mathrm{Fe}(\mathrm{III})$ reduction). Both Fe(III) and $\mathrm{As}(\mathrm{V})$ reduction were stimulated by spiking additional acetate and at the same time as a remarkable shift in the microbial population, with increased numbers of the family Geobacteraceae from 11 to $70 \%$ of total clones analysed. The linkage of microorganismdriven $\mathrm{As}(\mathrm{V})$ reduction with As mobilisation in paddy soils was evidenced by the highly frequent presence of respiratory $\mathrm{As}(\mathrm{V})$ reductase gene $(\operatorname{arr} A)$ and, on the other hand, by the observation of As released in the sterile soil inoculated with an $\mathrm{As}(\mathrm{V})$ reducing bacterium, Geobacter sp. OR-1, which was isolated from the same soil (Ohtsuka et al. 2013). Methylation of As in paddy soils was suggested to be a microbial-mediated process based on the high phylogenetic diversity of microorganism containing ars $M$ genes in soils and the positive correlation between the concentrations of methyl As species and the abundance of the ars $M$ gene in the soil (Jia et al. 2013). One of the most careful studies done on the linkage between As geochemistry and microbial activities may be that by Demergasso et al. (2007). The involvement of microbial activities in the precipitation process of As sulphides in Andean salt flats in northern Chile was demonstrated from several different aspects: (1) the enrichment and isolation of microbial cultures with As precipitation capacity from As mineral samples, (2) the high abundance of Asprecipitating bacteria found in the Andean minerals and brines, (3) the similarities in stoichiometry between natural and laboratory obtained biogenic sulphide minerals, and (4) the consistent depletion in $\delta^{34} \mathrm{~S}$ values for natural versus laboratory obtained sulphides.

The aforementioned studies on natural systems clearly revealed that microorganisms are the major player to drive the As cycling in the surface environment. In comparison, the model incubations under well-defined experimental conditions are able to better define the influence of microbial processes on As biogeochemical behaviour, the current state of knowledge of which will be reviewed in the following sections. Thus, the goal of this review article is to provide a comprehensive overview on the interplay between microorganisms and As geochemistry, which includes physical interactions with microbial cells, microorganism-mediated chemical transformation and processes induced by other microbial processes. This review provides a junction between the geochemical behaviour of As, microorganism-mediated process reactions and microbial matrix-mediated interactions with As. The knowledge generated here on As behaviour in the environment is essential for accurate assessment of the threat of As contamination to human and environmental health, as well as for the development of novel technologies for bioremediation of Ascontaminated soils and sediments.

\section{Microbial Intracellular and Extracellular Sequestration}

There seems to be no specific As uptake pathway for microorganisms since As does not play any metabolic or nutrimental role in the cell cytoplasm (Tsai et al. 2009). Arsenic enters cells via existing transporting systems, such as phosphate transport for $\operatorname{As}(\mathrm{V})$, due to the similar 
chemical structure (Tsai et al., 2009). Arsenite (As(III)) mostly presents as the noncharged form at environmental and physiological $\mathrm{pH}$. Thus, the aquoporin transporter may be responsible for As(III) entering cells. Therefore, microorganisms develop different strategies to detoxify intracellular cells by either excluding As from the cell or binding As in cells (Fig. 1). The extracellular polymeric substance (EPS) matrix on the cell surface can act as a molecular sieve, sequestering cations, anions, apolar compounds and particles from the water phase (Flemming and Wingender 2010). The EPS contains apolar regions, groups with hydrogen-bonding potential, anionic groups (e.g. in uronic acids and proteins) and cationic groups (e.g. in amino sugars) (Poli et al. 2011). Owing to this stickiness of the matrix, particles and nanoparticles can be trapped and accumulated. Interestingly, heavy metals such as $\mathrm{Zn}^{2+}, \mathrm{Cd}^{2+}$ and $\mathrm{Ni}^{2+}$ bind to the cell walls of bacteria, whereas hydrophobic compounds such as benzene, toluene and xylene are present in the matrix (Flemming and Wingender 2010). Thus, it is plausible that microorganisms have physical interactions with As both intra- and extracellularly. In this section, the potential of microbial intra- and extracellular physical interaction is discussed, including biosorption, bioaccumulation and the influence of the cell surface on As sorption.

\subsection{Biosorption}

To date, most knowledge related to the retention of trace elements on the microbial cell surface is focussed on cationic elements (Gadd 2009). Recent growing interest in the biosorption of As species with microorganisms has enabled an insight in more depth into the interaction between As and the microbial cell surface (Giri et al. 2013; Miyatake and Hayashi 2011; Prasad et al. 2011; Yan et al. 2010). The sorption of As(III), As(V) and monomethylarsonic acid has been evidenced with Bacillus subtilis (Hossain and Anantharaman 2006), Bacillus cereus (Giri et al. 2013), Acidithiobacillus ferrooxidans ( $q_{\max }$, $0.19 \mathrm{mg} \mathrm{g}^{-1}$ for As(III) and $0.22 \mathrm{mg} \mathrm{g}^{-1}$ for monomethylarsonic acid at $\mathrm{pH}$ 4) (Chandraprabha and Natarajan 2011; Yan et al. 2010), Rhodococcus sp. WB$12\left(q_{\max }, 77.3 \mathrm{mg} \mathrm{g}^{-1}\right.$ for As(III) at $\mathrm{pH}$ 7.0) (Prasad et al. 2011), Halobacterium saccharovorum, Halobacterium salinarium and Natronobacterium gregoryi (Williams et al. 2013). Sorption of As to bacterial cell surface was indicated in the form of electrostatic interaction involving hydroxyl, amide and amino groups on the microorganism surface (Giri et al. 2013; Prasad et al. 2011; Yan et al. 2010). Such interaction is $\mathrm{pH}$ dependent and was explained by variable surface charge behaviour with changing pH (Giri et al. 2013). In the case of living Bacillus cereus, the highest As(III) adsorption content was at pH 7.5 (Giri et al. 2013). Similarly, characterising the $\mathrm{pH}$ dependent $\mathrm{As}(\mathrm{V})$ and $\mathrm{As}(\mathrm{III})$ sorption behaviour onto dry B. cereus $\mathrm{W} 2$ and Rhodococcus sp. WB-12 showed the highest adsorption extents for both As species at around pH 7 (Miyatake and Hayashi 2011; Prasad et al. 2011). Thermodynamic characterisation based on the investigations from 15 and 20 to $40{ }^{\circ} \mathrm{C}$ of living B. cereus and A. ferrooxidans BY-3 revealed that this sorption process is

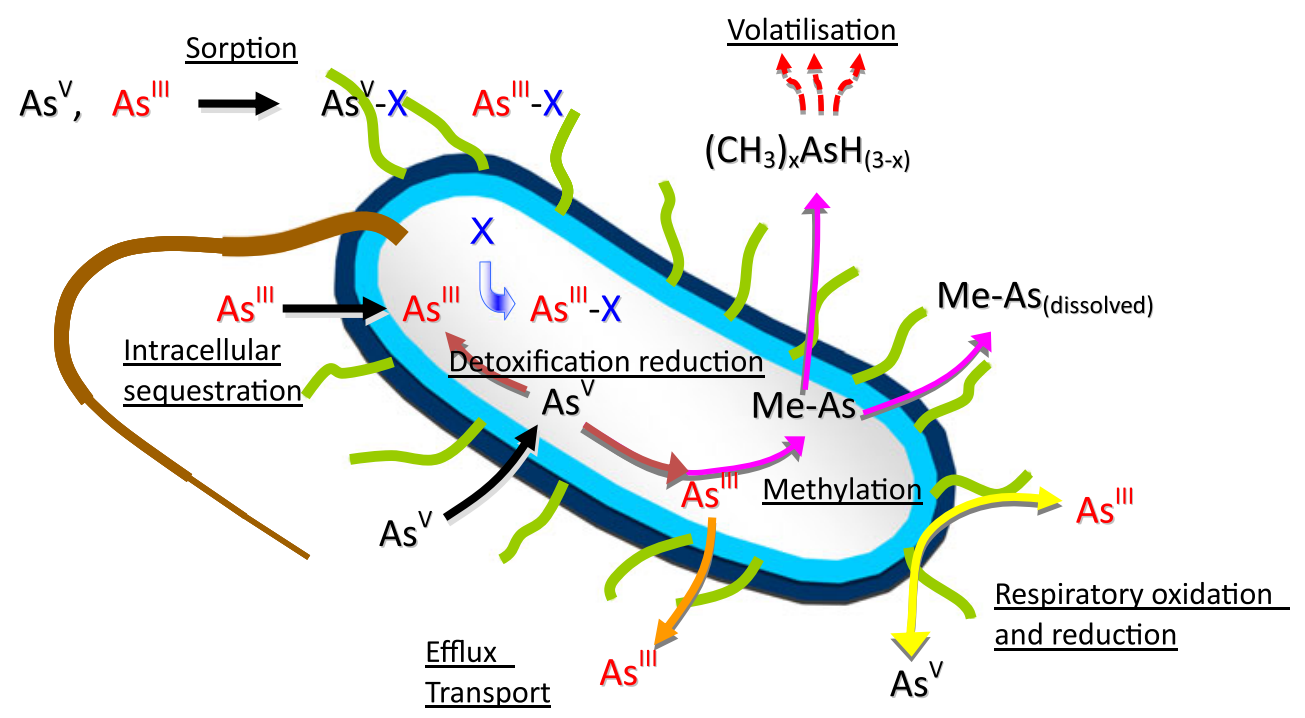

Fig. 1 Overview of the interaction between microorganism and arsenic compounds 
spontaneous and endothermic with a usually higher sorption extent observed at higher temperatures (Giri et al. 2013; Yan et al. 2010). On the other hand, As(III) and $\mathrm{As}(\mathrm{V})$ adsorption capacities onto dry B. cereus W2 cells first increased from 20 to $30{ }^{\circ} \mathrm{C}$ and thereafter decreased from 30 to $60{ }^{\circ} \mathrm{C}$ (Miyatake and Hayashi 2011). Whether the living status of microbial cells plays a role in such discrepancies is not clear. Giri et al. (2013) proposed the formation of an inner-sphere complex between As(III) and the surface of B. cereus in the neutral $\mathrm{pH}$ range; however, further research is required to prove this hypothesis. Among different As species, monomethylarsonic acid sorption was favoured over $\mathrm{As}(\mathrm{III})$ at the surface of A. ferrooxidans (Yan et al. 2010). Chandraprabha and Natarajan (2011) highlighted another As binding mechanism to the cell surface via the precipitation of $\mathrm{As}(\mathrm{V})$ by $\mathrm{Fe}(\mathrm{II})$ present in the EPS of ferrous grown A. ferrooxidans. The formation of nano-particled amorphous $\mathrm{Fe}$ (hydr)oxides precipitating on the cell surface by adding $\mathrm{Fe}(\mathrm{III})$ may also largely increase the $\mathrm{As}(\mathrm{III})$ and $\mathrm{As}(\mathrm{V})$ sorption capacity via the formation of inner-sphere complexes (Yang et al. 2012).

\subsection{Microbial Competitive Adsorption}

Microbial cells attached to minerals facilitate a series of reactions ranging from the retardation of toxins adsorbed to their surface, to the accelerated weathering of minerals (Dong 2010). Recently, microbial attachment to minerals was identified as an important factor leading to the increased solubility of $\mathrm{As}(\mathrm{V})$ via competition between $\mathrm{As}(\mathrm{V})$ and bacterial phosphate and carboxylate groups for $\mathrm{Fe}$ (III)-(oxyhydr)oxide surface sites (Huang et al. 2011a). Conversely, Kim et al. (2010) indicated a negligible influence of the bacterial cells of Enterococcus faecalis, Escherichia coli and B. subtilis on $\mathrm{As}(\mathrm{III})$ and $\mathrm{As}(\mathrm{V})$ adsorption to Fe-impregnated granular activated carbon. One potential explanation is the lower cell density $\left(10^{8} \mathrm{CFU} \mathrm{mL}^{-1}\right)$ used in the study by Kim et al. (2010) compared to that used in Huang et al. (2011a) $\left(5 \times 10^{9}\right.$ cells $\left.\mathrm{mL}^{-1}\right)$. Whether the difference of bacterial strains plays an important role, however, remains an open question.

\subsection{Bioaccumulation}

Although there is wide distribution of As-resistant microorganisms in the environment, comparably small amounts of microorganisms are known to hyper- accumulate As (non-genetically engineered microorganisms) (Xie et al. 2013). Different from biosorption, bioaccumulation infers intracellular accumulation of As in, e.g. cell membranes and cytoplasm instead of at the cell surface (Joshi et al. 2009; Takeuchi et al. 2007; Xie et al. 2013). Usually, an effective strategy to bind As intracellularly is required to tolerate high amounts of As in cells aside from the classical ars operon detoxification, which pumps As out of the cell after reduction. Microorganisms may take advantage of several different strategies to bind As in cells such as the formation of As(III) complexes with chelating proteins or peptides containing thiol groups. For example, the metalloregulatory protein ArsR offers high affinity and selectivity toward As(III), which was used in engineered bacterial cells to accumulate As (Kostal et al. 2004). In the case of Bacillus sp. strain DJ-1, which accumulates As levels of up to $9.8 \mathrm{mg} \mathrm{g}^{-1}$ (dry weight), this occurs by binding As with the DNA protection during starvation protein using not only interaction with thiol but also ionic interactions with amino acids (Joshi et al. 2009).

\section{Microbial Arsenic Transformation}

Major transformations of As in the environment include microbial oxidation, reduction, methylation and demethylation (Fig. 1). These transformation reactions have an enormous impact on the environmental behaviour of As, as the different chemical forms of As exhibit different mobility [methyl As(III) $>>$ methyl As(V)>As(III) > As(V)] (Lafferty and Loeppert 2005), toxicity [methyl As $($ III $)>\operatorname{As}($ III $)>\operatorname{As}(\mathrm{V})>$ methyl As(V)] (Petrick et al. 2000) and susceptibility to plant uptake [e.g. uptake by the rice root $\mathrm{As}(\mathrm{III})>$ monomethyl $\mathrm{As}(\mathrm{V})>$ dimethyl As(V)] (Abedin et al. 2002). Generally, As transformation in the environment is mostly biotic (Meng et al. 2003). Abiotic transformation of As has been shown to be substantially slower and is believed to be less important than microbially mediated reduction (Ahmann et al. 1997; Jones et al. 2000; Newman et al. 1997b). For example, the reduction of $\mathrm{As}(\mathrm{V})$ by sulphide was kinetically much slower than As(V) reduction by Desulfotomaculum auripigmentum strain OREX-4, and thiosulphate and sulphite showed negligible reductions of As(V) (Newman et al. 1997b). Thermus aquaticus and Thermus thermophilus have been shown to oxidise $\mathrm{As}(\mathrm{III})$ to $\mathrm{As}(\mathrm{V})$ 100-fold faster than abiotic controls in laboratory experiments (Gihring et al. 2001). The 
mechanisms and physiological aspects related to microbial As transformation have been detailed in many review articles (Kruger et al. 2013; Lloyd and Oremland 2006; Mukhopadhyay et al. 2002; Paez-Espino et al. 2009; Silver and Phung 2005). Thus, this section will focus on the knowledge concerning the interplay between microbial As transformation and its geochemical behaviour.

\subsection{Arsenite Oxidation}

Microbial As(III) oxidation is a potential detoxification process that allows microorganism to tolerate higher As(III) levels (Paez-Espino et al. 2009; Tamaki and Frankenberger 1992). Additionally, As(III) oxidation may serve as an electron donor for microbial respiration in combination with $\mathrm{O}_{2}$ or nitrate under oxic and anoxic conditions (Paez-Espino et al. 2009). Arsenite oxidation is catalysed by a wide range of microorganisms, e.g. Alcaligenes faecalis, Hydrogenophaga sp., A. ferrooxidans, T. aquaticus, T. thermophilus, etc. (Gihring et al. 2001; Oremland and Stolz 2003; Stolz et al. 2006; Wang and Zhao 2009). The major impact of microbial oxidation of $\mathrm{As}(\mathrm{III})$ to $\mathrm{As}(\mathrm{V})$ is to reduce As mobility in the environment as the affinity of $\mathrm{As}(\mathrm{V})$ to mineral solids is usually higher than that of $\mathrm{As}$ (III) (Dixit and Hering 2003; Huang et al. 2011c; Smedley and Kinniburgh 2002). Microbial As(III) oxidation has been proposed for As removal from polluted water (Cavalca et al. 2013; Ito et al. 2012). Arsenic immobilisation enhanced by the simultaneous microbial oxidation of $\mathrm{As}(\mathrm{III})$ and $\mathrm{Fe}(\mathrm{II})$ has been considered as a potential bioremediation strategy of As in anoxic environment. This is based on the formation of Fe(III) (hydr)oxides, which adsorbed As(V) formed from As(III) oxidation (Inskeep et al. 2004; Sun 2008).

\subsection{Arsenate Reduction}

Reduction of $\mathrm{As}(\mathrm{V})$ generally indicates an increase in As mobility in the natural environment, as As(III) is generally more mobile than $\mathrm{As}(\mathrm{V})$ (Ahmann et al. 1997; Smedley and Kinniburgh 2002). Microbial reduction of $\mathrm{As}(\mathrm{V})$ may occur via respiratory reduction, as microorganisms use $\mathrm{As}(\mathrm{V})$ as the terminal electron acceptor in anaerobic respiration (Lloyd and Oremland 2006; Mukhopadhyay et al. 2002; Stolz et al. 2002, 2006), e.g. bacteria (Sulfurospirillum barnesii, Bacillus arsenicoselenatis, Bacillus selenitireducens, Sulfurospirillum arsenophilum, Desulfotomaculum auripigmentum, Chrysiogenes arsenatis and Desulfomicrobium strain Ben-RB) (Macy et al. 2000; Newman et al. 1998, 1997b; Stolz and Oremland 1999) and hyperthermophilic archaea (Pyrobaculum arsenaticum and Pyrobaculum aerophilum) (Huber et al., 2000). Another mechanism of microbial reduction of $\mathrm{As}(\mathrm{V})$ to $\mathrm{As}(\mathrm{III})$ is through detoxification (Langner and Inskeep 2000; Stolz et al. 2002). Arsenic detoxification has been documented in E. coli, Staphylococcus aureus and Staphylococcus xylosis, and is controlled by ars genes that encode for As(V) (Cervantes et al. 1994; Tamaki and Frankenberger 1992). Arsenate detoxifying reducing bacteria were found to play a major role in As mobilisation under oxic conditions. In the flooding soil amended with citrate, strong As mobilisation was observed at the beginning of incubation when oxic conditions prevailed $(\mathrm{Eh}>250 \mathrm{mV}$ ) (Corsini et al. 2010). The predominant As(III) appearance in soil solution appeared to be due to the detoxifying activity of Asresistant bacteria with ars genes, which were identified as Bacillus and Pseudomonas spp. Nevertheless, As(V) became prevalent as a consequence of As liberation driven by reductive dissolution of $\mathrm{Mn}$ and $\mathrm{Fe}$ (hydr)oxides by Geobacter spp. and inhibiting the growth and activity of $\mathrm{As}(\mathrm{V})$-resistant bacteria. Apparently, there was a lack of $\mathrm{As}(\mathrm{V})$ respiratory reducing bacteria in the aforementioned soils. Studies of Shewanella strain ANA3 with or without ArrA suggest that ArsC does not contribute significantly to total $\mathrm{As}(\mathrm{V})$ reduction when soluble $\mathrm{As}(\mathrm{V})$ concentrations are in the low micromolar range and the reduction kinetics of $\mathrm{As}(\mathrm{V})$ was much faster via respiration than detoxification (Campbell et al. 2006; Malasarn et al. 2004).

Respiratory $\mathrm{As}(\mathrm{V})$ reduction has been shown to be capable of mobilising solid associated As(V), including adsorbed and mineral As(V) (Babechuk et al. 2009; Huang et al. 2011c; Zobrist et al. 2000). The rate of $\mathrm{As}(\mathrm{V})$ reduction is known to be influenced by the binding forms in which $\mathrm{As}(\mathrm{V})$ became associated with the mineral phases and coupled strongly with $\mathrm{As}(\mathrm{V})$ adsorption and desorption rates. The microbial $\mathrm{As}(\mathrm{V})$ reduction rate was found to decrease in the order: dissolved $>>A s(V)$ added to ferrihydrite suspensions at the start of the incubation $>\mathrm{As}(\mathrm{V})$ reacted with ferrihydrite for $24 \mathrm{~h}$ before incubation $>\mathrm{As}(\mathrm{V})$ co-precipitated during ferrihydrite synthesis (Zobrist et al. 2000). Microbial As(V) reduction kinetics studies undertaken in mineral suspensions without growth medium highlight that the presence of mineral sorbents resulted in pronounced decreases in reduction 
rates and the magnitude of this effect increased with increasing sorbent concentration and sorption capacity (Huang et al. 2011d). Due to the very low affinity of $\mathrm{As}(\mathrm{III})$ to $\mathrm{Al}$ (hydr)oxides, $\mathrm{As}(\mathrm{V})$ reduction to $\mathrm{As}(\mathrm{III})$ will largely enhance the solubility of $\mathrm{As}$ at the water-Al (hydr)oxide interface. Reductive dissolution of Alferrihydrite by Shewanella sp. ANA-3 results in the enrichment of $\mathrm{Al}$ sites and $\mathrm{As}(\mathrm{V})$ reduction accelerates $\mathrm{As}$ release due to the low affinity of As(III) on these nonferric sites (Masue-Slowey et al. 2011).

Malasarn et al. (2008) characterised in detail the location of Shewanella sp. strain ANA-3 As(V) respiratory reductase, showing that the enzyme localises to the periplasm in intact cells. Since direct contact between enzyme and substrate is necessary for reaction, this finding suggests that microbial respiratory reduction of solid associated $\mathrm{As}(\mathrm{V})$ is infeasible. However, the authors have verified the release of $\mathrm{As}(\mathrm{V})$ reductase from ANA-3 into the surrounding environment and the fact that this remains active for a while, which is suggested to be a general phenomenon of $\mathrm{As}(\mathrm{V})$ respiratoryreducing bacteria. The presence of cell-free ARR in the environment may be relevant if electron donors with sufficiently low redox potentials are present to allow the enzyme to catalyse $\mathrm{As}(\mathrm{V})$ reduction. Redox active small molecules, including natural products, could possibly serve this purpose, although this hypothesis has yet to be tested. Respiratory $\mathrm{As}(\mathrm{V})$ reduction may inhibit or be inhibited by the other redox processes. Nitrate inhibited $\mathrm{As}(\mathrm{V})$ reduction by nitrate reduction as a preferred respiratory electron acceptor rather than as a structural analogue of $\mathrm{As}(\mathrm{V})$. Bacterial sulphate reduction was completely inhibited by $\mathrm{As}(\mathrm{V})$ reduction as well as by As(III) (Dowdle et al. 1996). D. auripigmentum strain OREX-4 was shown to be able to respiratory-reduce $\mathrm{As}(\mathrm{V})$ and sulphate, but was found to prefer sulphate (Newman et al. 1997b).

\subsection{Methylation}

Biogenic As volatilisation was budgeted as the input at $26,000 \mathrm{t}_{\text {year }}{ }^{-1}$, accounting for $58 \%$ of natural emissions and $36 \%$ of total As emission (Chilvers and Peterson 1987). Arsenic methylation was demonstrated by different aerobic and anaerobic microorganisms (Table 1) (Kuehnelt and Goessler 2003). Until 2006, there have been more than 125 bacterial and 16 archaeal ArsM homologues identified (Qin et al. 2006) and more microorganisms capable of As methylation are expected. Microbial methylation allows the transformation of aqueous- or solid-associated inorganic As into gaseous arsines and leaves from the living medium, which is usually regarded as a detoxification (Jia et al. 2013). The gaseous arsines are highly mobile in comparison to aqueous As and may undergo long-distance transport in the atmosphere (Mukai et al. 1986). The formation of aqueous trivalent and pentavalent methyl As were also reported and was considered mobilisation due to the lower adsorption affinity of methylated As than inorganic As (Huang and Matzner 2006; Lafferty and Loeppert 2005). Low redox potentials (i.e. reducing conditions) promote the production and mobilisation of methylated As (Frohne et al. 2011). Under reducing conditions, the reductive dissolution of $\mathrm{Fe} / \mathrm{Mn}$ (hydr)oxide mineral sorbents and the reduction of $\mathrm{As}(\mathrm{V})$ to As(III) may increase the levels of dissolved As in soils and sediments (Bennett et al. 2012; Du Laing et al. 2009) and thereby enhance subsequent microbial methylation of As. Cullen et al. (1994) identified the extracellular As metabolites in the growth medium of Apiotrichum humicola and Scopulariopsis brevicaulis and the methylation was as follows: inorganic As $\rightarrow$ monomethylarsonic acid $\rightarrow$ dimethylarsinic acid $\rightarrow$ trimethylarsine oxide. Monomethylarsonic acid was shown to be an intermediate, which is hardly excreted due to its low permeability and rapid intracellular metabolism. Dimethylarsinic acid was 10 times more permeable to the membranes than monomethylarsonic acid and thus explains the generally much lower concentrations of monomethylarsonic acid in most natural environments compared to dimethylarsinic acid (Blodau et al. 2008; Fauser et al. 2013; Hasegawa et al. 2009; Huang and Matzner 2007). Intracellular methylation of $\mathrm{As}(\mathrm{V})$ in Trichoderma asperellum, Penicillium janthinellum and Fusarium oxysporum revealed the formation As(III), monomethylarsonic acid and dimethylarsinic acid in cells and highlights the fact that intracellular $\mathrm{As}(\mathrm{V})$ reduction progresses more easily than methylation (Su et al., 2012). Instead of aqueous methyl As, numerous studies showed the formation of gaseous methyl arsines such as Methanobacterium bryantii (McBride 1971), Methanobacterium formicium, Clostridium collagenovorans, Desulfovibrio gigas and Desulfovibrio vulgaris (Michalke et al. 2000). Trivalent methyl As (monomethylarsonous acid and dimethylarsinous acid) were proposed to be the intermediates of As methylation according to Challenger's pathway, and have been detected in both environmental samples (Huang et al. 2011b; McKnight-Whitford et al. 2010) 
and human cells (Hippler et al. 2011). However, both monomethylarsonous acid and dimethylarsinous acid have not yet been found during microbial As methylation. As indicated, the ability to methylate $\mathrm{As}(\mathrm{III}), \mathrm{As}(\mathrm{V})$ or methyl As and the chemical forms of methyl As produced seems to be microorganism dependent (Table 1). To date, As(III) S-adenosyl-methionine methyltransferase has been the most frequently investigated methylation pathway for As(III) (Qin et al. 2006; Yuan et al. 2008), showing methyl arsines as the products. Nevertheless, the summary in Table 1 highlights that most microorganisms are able to methylate As using $\mathrm{As}(\mathrm{V})$ as starting compounds and dissolved methyl As may be the product instead of methyl arsines. This suggests that either microorganisms have the ability to reduce As(III) or use other methylation pathways for methylation directly using As(V). Although several methylation pathways have been proposed (Mestrot et al. 2013; Wu 2005; Wuerfel et al. 2012), the current state of knowledge is still not able to explain the occurrence of methyl As of different chemical forms in nature and their linkage to the different enzymatic systems involved in microbial methylation; e.g. As(V) reductase, monomethylarsonic acid reductase, As(III) methyltransferase and monomethylarsonous acid methyltransferase (Wu 2005).

\subsection{Demethylation}

Demethylation may occur under oxic and anoxic conditions but is usually faster under oxic conditions (Huang et al. 2007). Elimination of the organic moieties not only increases the general toxicity of As but also decreases its mobility. Thus, demethylation is apparently not suitable for the purpose of remediation and therefore draws relatively few research interests. Although microbial As demethylation has been broadly evidenced in the natural environment (Huang et al. 2007; Khokiattiwong et al. 2001; Millward et al. 1996; Sierra-Alvarez et al. 2006), characterisation of microbial demethylation and investigation of microbial community involved is scarce. Yoshinaga et al. (2011) identified Burkholderia and Streptomyces species in contaminated soils as being responsible for monomethylarsonic acid reduction and monomethylarsonous acid demethylation. Only a mixed culture could perform the complete process of demethylation, demonstrating that monomethylarsonic acid demethylation to $\mathrm{As}(\mathrm{III})$ is a two-step process. Mycobacterium neoaurum was found to demethylate both monomethylarsonic acid and monomethylarsonous acid to mixtures of $\mathrm{As}(\mathrm{V})$ and As(III) (Lehr et al. 2003). Arsenic demethylation usually refers to the degradation of aqueous methylated As. In the atmosphere, the gaseous methylated arsines undergo rapid photooxidative degradation (Mestrot et al. 2011). Whether the microorganisms present in the atmosphere are able to carry out As demethylation is still an open question.

\section{Influence of Other Microbial Redox Reactions on Arsenic Geochemistry}

Almost all of the natural redox reactions may influence As environmental behaviour. They may shift the redox equilibrium between $\mathrm{As}(\mathrm{III})$ and $\mathrm{As}(\mathrm{V})$, and may also dissolve and precipitate minerals, substantially changing the mobility of As. The most well-known processes among all are microbial $\mathrm{Fe}$ and $\mathrm{S}$ reduction and oxidation. Figure 2 shows a schematic presentation of the interaction among As, Fe and S oxidation and reduction. The redox transformation of Fe, S and As is predominately driven by microorganisms, but abiotic As transformation coupled with $\mathrm{Fe}$ and $\mathrm{S}$ redox transformation may also occur. Formation of $\mathrm{Fe}$ (II) and $\mathrm{Fe}(\mathrm{III})$ (hydr)oxides, sulphide and As(V) minerals during biogeochemical cycling will be the major sink for the solution As. Discussion about the known interplay between other microbial redox reactions and As behaviour are given in the following sections and detailed information is summarised in Table 2.

\subsection{Nitrate Reduction}

Nitrate reduction may not only inhibit $\mathrm{As}(\mathrm{V})$ reduction (see Section 3.2) (Dowdle et al. 1996) but can also influence As cycling under anoxic conditions. For example, nitrate-respiring sediments could reduce $\mathrm{As}(\mathrm{V})$ to As(III) once all of the nitrate has been removed (Gibney and Nusslein 2007). In urban lakes, microbial oxidation of $\mathrm{Fe}$ (II) and As(III) facilitated by nitrate may be a significant process leading to the formation of particulate ferric-oxide and $\mathrm{As}(\mathrm{V})$; an important consequence of enriched nitrate is therefore the presence of $\mathrm{As}(\mathrm{V})$ associated with hydrous ferric oxide colloids (Senn and Hemond 2002). Injecting nitrate may support the anoxic oxidation of $\mathrm{Fe}(\mathrm{II})$ and $\mathrm{As}(\mathrm{III})$ in the subsurface as a means to immobilise As in the form of As(V) adsorbed onto biogenic Fe(III) (hydr)oxides (Sun et al. 2009). 


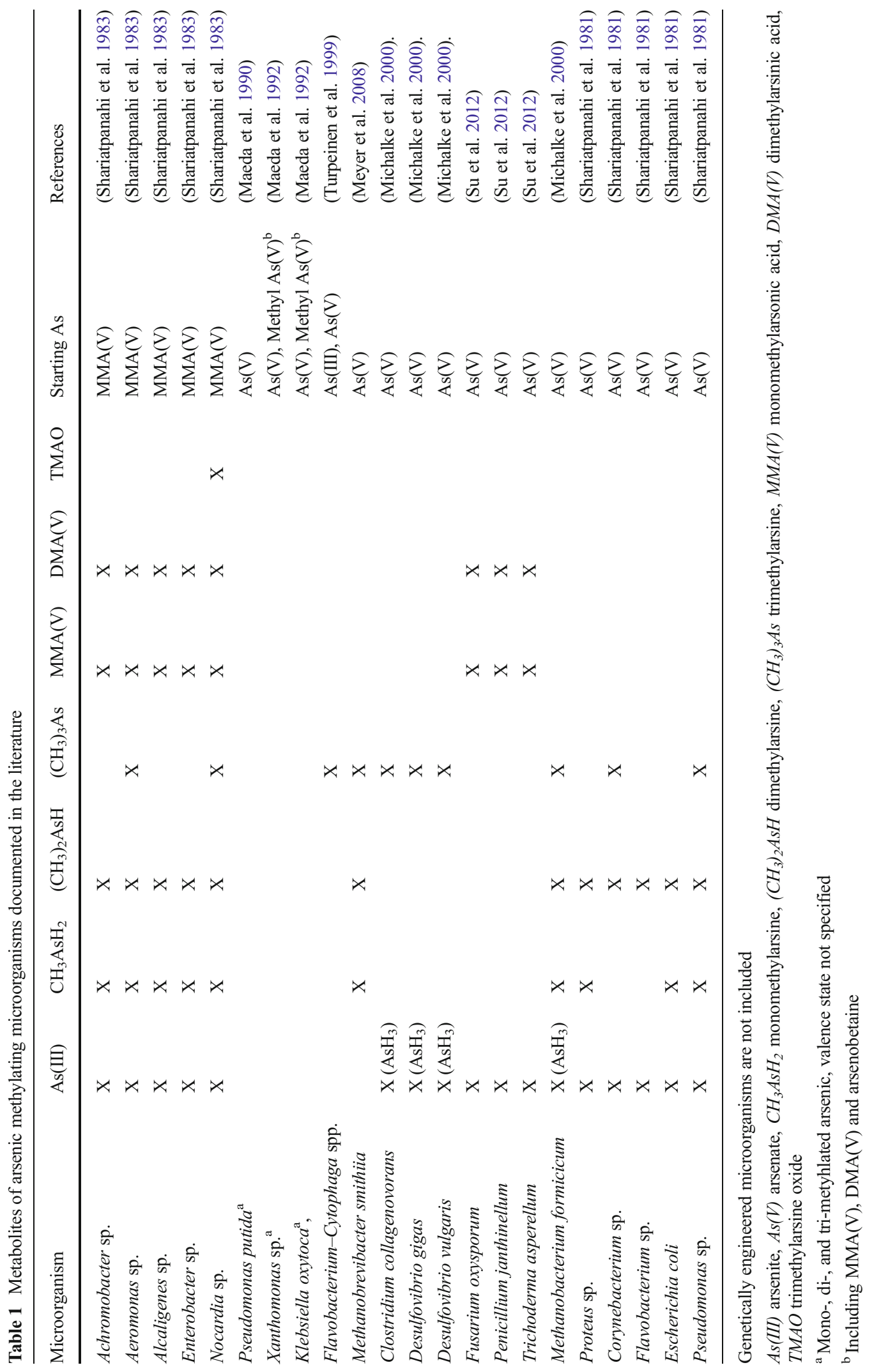




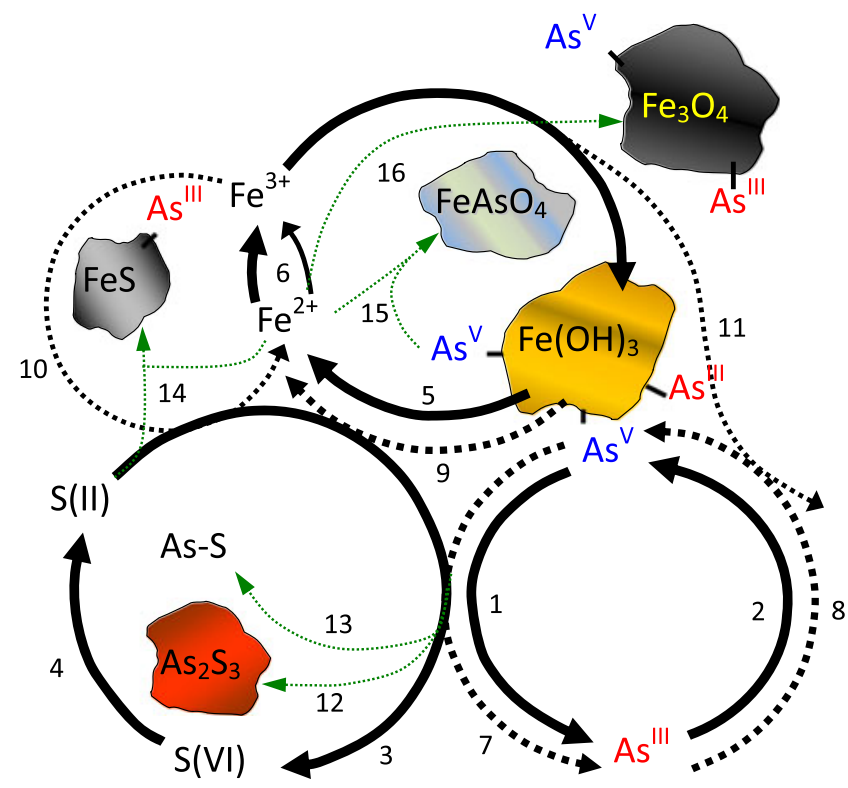

Fig. 2 Overview of the interaction between microbial (solid lines) and microorganism mediated processes (dash lines) of $\mathrm{Fe}, \mathrm{S}$ and As redox transformation influencing As compounds. (1) microbial As(V) reduction; (2) microbial As(III) oxidation; (3) microbial sulphide oxidation; (4) microbial sulphidisation; (5) microbial Fe(III) reduction; (6) microbial Fe(II) oxidation; (7) sulphide

\subsection{Iron Reduction}

There are a number of microorganisms known to be responsible for reducing $\mathrm{Fe}$ in the reducing environment. The most famous are Geobacter spp. and Shewanella spp. (Lovley et al. 2004). Generally, reductive As mobilisation is attributed to microbial Fe reductive dissolution, which is concluded mostly based on field observations (Corsini et al. 2010; Cummings et al. 1999; Huang and Matzner 2006; Islam et al. 2004; Tadanier et al. 2005). Corsini et al. (2010) demonstrated that microbial $\mathrm{Fe}$ reduction was the major process that caused As mobilisation in flooded soils when microbial $\mathrm{As}(\mathrm{V})$ respiratory activity was lacking. Microbially mediated reduction of Fe(III) (hydr)oxides was shown to be capable of promoting As mobilisation from a crystalline ferric arsenate as well as from sorption sites (Cummings et al. 1999). Tadanier et al. (2005) suggested microbially-mediated deflocculation of Fe(III) (hydr)oxide nanoparticles from an initially aggregated particulate configuration to smaller filterable colloids as the dominant mechanism of As mobilisation. Nevertheless, As mobilisation via reductive dissolution of $\mathrm{Fe}$ (hydr)oxides, especially amorphous phases with very high As adsorption capacity, is doubtful when looking induced $\mathrm{As}(\mathrm{V})$ reduction; (8) abiotic As(III) oxidation; (9) sulphide-induced Fe(III) reduction; (10) ferric ion-induced sulphide oxidation; (11) ferric ion-induced As(III) oxidation; (12) arsenic sulphide precipitation; (13) formation of aqueous thioarsenic complexes; (14) iron sulphide precipitation; (15) ferrous arsenate precipitation; (16) formation of secondary Fe(II) minerals

into the results from a series of lab model experiments: Simulating microbial Fe reduction with ascorbic acid indicated that adsorbed $\mathrm{As}(\mathrm{V})$ was not released until the surface area of ferrihydrite and goethite became too small (Pedersen et al. 2006). It is thus plausible that increased As mobilisation at the water-ferrihydrite interface via $\mathrm{Fe}$ (III) reductive dissolution was indicated to be only relevant at high $\mathrm{As}(\mathrm{V})$ to ferrihydrite ratios (Jiang et al. 2013). On the other hand, several model experiments have shown that the formation of secondary $\mathrm{Fe}$ (II) (hydr)oxides, e.g. magnetite $\left(\mathrm{Fe}_{3} \mathrm{O}_{4}\right)$, vivianite $\left[\mathrm{Fe}_{3}\left(\mathrm{PO}_{4}\right)_{2} \cdot 8 \mathrm{H}_{2} \mathrm{O}\right]$ siderite $\left(\mathrm{FeCO}_{3}\right)$ and bobierrite $\left[\mathrm{Mg}_{3}\left(\mathrm{PO}_{4}\right)_{2} \cdot 8 \mathrm{H}_{2} \mathrm{O}\right]$ during microbial reduction may trap released As again, depending on the composition of the working solution (Burnol et al. 2007; Coker et al. 2006; Herbel and Fendorf 2006; Islam et al. 2005). Additionally, $\mathrm{As}(\mathrm{V})$ bound more strongly after $\mathrm{Fe}^{2+}$ catalysed ferrihydrite and lepidocrocite $[\gamma-\mathrm{FeO}(\mathrm{OH})]$ transformation into more crystalline $\mathrm{Fe}(\mathrm{III})$ oxide phases or magnetite, leading to the incorporation of As into the structure of the crystalline product (Pedersen et al. 2006). Similar to ferrihydrite, no apparent As mobilisation was observed during reduction of schwermannnite due to the formation of biogenic minerals (Cutting et al. 2012). Recently, incubations with different Shewanella strains 


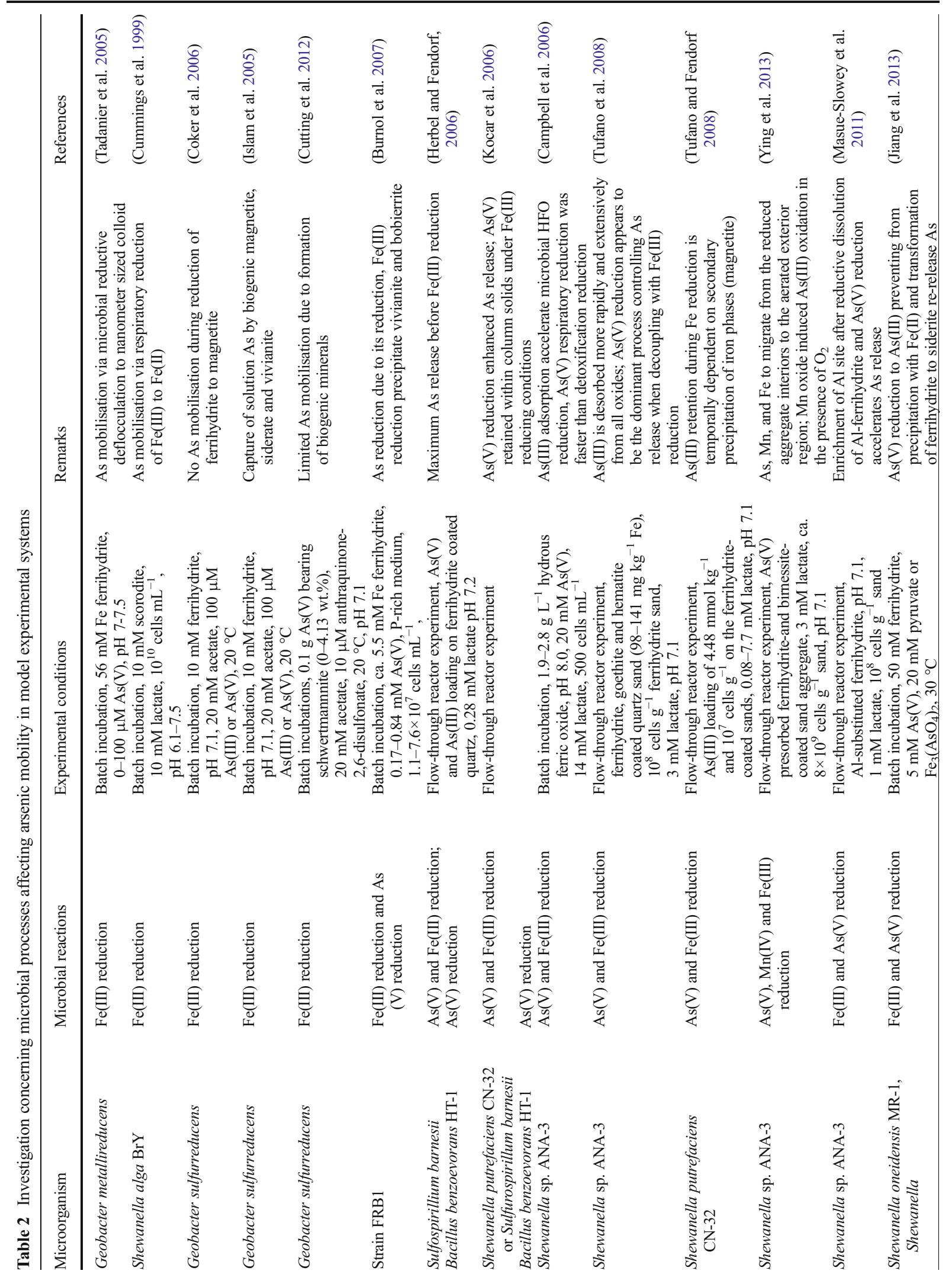




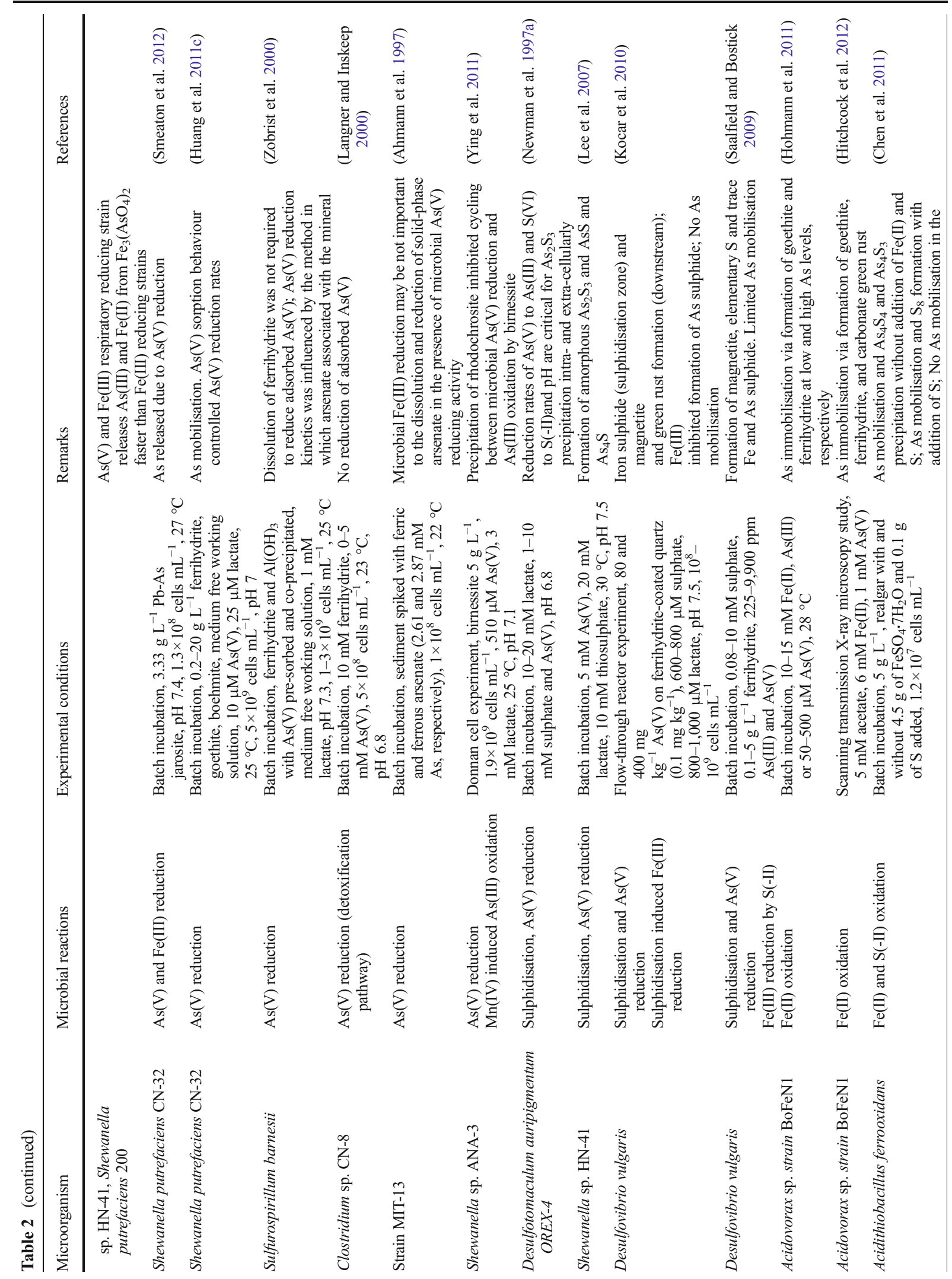


suggested that microbial $\mathrm{Fe}(\mathrm{III})$ reduction is able to immobilise As via the formation of $\mathrm{Fe}_{3}\left(\mathrm{AsO}_{4}\right)_{2}$ precipitation and that the parallel $\mathrm{As}(\mathrm{V})$ reduction to $\mathrm{As}(\mathrm{III})$ prevents precipitation with Fe(II) (Jiang et al. 2013). In summary, the model experiments showed highly controversial results of the influence of microbial Fe reduction on As mobility, although most field studies highlight As mobilisation as a consequence of microbial reductive dissolution of $\mathrm{Fe}(\mathrm{III})$ (hydr)oxides. Recently, a study of As behaviour in wetland soils allowed the first explanation of this discrepancy. It showed that the presence of organic matter reduced or inhibited the formation of secondary Fe(II) minerals during reductive dissolution of Fe(III) (hydr)oxide and that As was not taken up and was thereby strongly solubilised (Davranche et al. 2013). It appears that the complexity of the natural system provides plenty of possibilities to influence the transformation of $\mathrm{Fe}$ (hydr)oxides with a consequent effect on As mobility, which should be more comprehensively investigated in future model experiments.

Abiotic reduction of $\mathrm{As}(\mathrm{V})$ by $\mathrm{Fe}(\mathrm{II})$ produced by microbial $\mathrm{Fe}(\mathrm{III})$ reduction is unlikely. In an abiotic control experiment, Zobrist et al. (2000) checked for possible $\mathrm{As}(\mathrm{V})$ reduction in the presence of $\mathrm{Fe}(\mathrm{II})$ in ferrihydrite suspensions, but detected no As(III) in solution or sorbed to the solid phase. Similarly, Amstaetter et al. (2010) observed no reduction of As(V) under strictly anoxic conditions by "Fe(II)-activated" goethite, i.e. goethite with adsorbed Fe(II). Surprisingly, however, the authors did observe oxidation of As(III) to As(V) by $\mathrm{Fe}(\mathrm{II})$-activated goethite under anoxic conditions, suggesting that $\mathrm{Fe}$ (II) on the goethite surface formed a highly reactive, As(III)-oxidising surface site of unknown nature.

\subsection{Manganese Oxidation and Reduction}

The information concerning the interaction between $\mathrm{Mn}$ oxidation and reduction and As is less than Fe redox transformation, probably because Mn oxides are usually a minor component compared to Fe (hydr)oxides in soils and sediments. Microbial Mn oxidation and reduction may act on As mobilisation similar to Fe(III) reduction since $\mathrm{Mn}(\mathrm{IV})$ oxides are also effective sorbents for As(V) (Ajith et al. 2013; Smedley and Kinniburgh 2002; Ying et al. 2012). The major difference with $\mathrm{Fe}$ (hydr)oxides is that Mn-oxides are quite reactive, with respect to As(III) oxidation to As(V), which substantially changes the As mobility. To date, As(III) oxidation by 
biogenic Mn oxides has been evidenced in bacteria and fungi (Liao et al. 2013; Ozaki et al. 2013; Tani et al. 2004; Ying et al. 2011). An interesting study based on Donnan cell experiments highlighted the potential cycling between microbial $\mathrm{As}(\mathrm{V})$ reduction and abiotic As(III) oxidation by bernessite $\left(\mathrm{MnO}_{2}\right)$ (Ying et al. 2011). Such As redox cycling ceased until the passivation of bernessite surface by precipitating rhodochrosite $\left(\mathrm{MnCO}_{3}\right)$. Whether the As cycling between microbial $\mathrm{As}(\mathrm{V})$ reduction and $\mathrm{Mn}$ oxide oxidation play a significant role in the natural environment is questionable. The simultaneous presence of $\mathrm{Mn}$ oxides and microbial $\mathrm{As}(\mathrm{V})$ reduction in the natural environment seems unlikely. As shown in redox priority sequence, the priority of $\mathrm{As}(\mathrm{V})$ reduction is generally lower than the reduction of $\mathrm{Mn}$ oxides, i.e. $\mathrm{As}(\mathrm{V})$ reduction may begin in the redox condition after Mn oxides have been completely reduced.

\subsection{Sulphidisation}

Although microbial reduction of $\mathrm{S}$ compounds into sulphide is frequently regarded as a process to trap solution As (O'Day et al. 2004), $\mathrm{As}_{2} \mathrm{~S}_{3}$ precipitation is sensitive to environmental conditions. Usually, $\mathrm{As}_{2} \mathrm{~S}_{3}$ precipitation favours acidic over basic conditions and microorganism-mediated precipitation of $\mathrm{As}_{2} \mathrm{~S}_{3}$ may occur both extracellularly and intracellularly (Newman et al. 1997a). Microorganism-mediated $\mathrm{As}_{2} \mathrm{~S}_{3}$ precipitation is a function of the ability of microorganisms to reduce As and $\mathrm{S}$ compounds to appropriate concentrations of $\mathrm{As}(\mathrm{III})$ and sulphide. The precipitation of $\mathrm{As}_{2} \mathrm{~S}_{3}$ occurs in anoxic waters essentially when dissolved sulphide and As(III) production exceeds their solubility products. On the other hand, investigation of precipitation of $\mathrm{As}_{2} \mathrm{~S}_{3}$ by D. auripigmentum and Desulfotomaculum propionicus demonstrated that D. propionicus reduce $\mathrm{S}(\mathrm{VI})$ too rapidly, leading to formation of $\mathrm{H}_{\mathrm{x}} \mathrm{AsS}_{6}{ }^{x-3}$ rather than $\mathrm{As}_{2} \mathrm{~S}_{3}$ precipitates (Newman et al. 1997a). When Fe concentrations are much higher than sulphide concentrations, As sequestration becomes controlled by $\mathrm{Fe}$ because aqueous sulphide is rapidly depleted during the formation of iron sulphide minerals (Kocar et al. 2010; Saalfield and Bostick 2009). The findings related to the influence of $\mathrm{Fe}-\mathrm{S}$ redox interaction during microbial sulphidisation on As mobility are controversial and at the same time show the high complexity of the natural system. Kocar et al. (2010) and Saalfield and Bostick (2009) both concluded As sequestration by the residual ferrihydrite and secondary Fe(II) minerals (magnetite) during sulphidisation. On the other hand, Burton et al. (2011) reported that sulphide-driven reductive dissolution of ferrihydrite and its replacement by mackinawite (FeS) resulted in the substantial mobilisation of As into the pore water. Formation of poorly sorbing aqueous thioarsenic species during microbial sulphidisation may cause the additional enhancement of As mobilisation (Burton et al. 2013). Accordingly, the change of not only the mineral composition but also As speciation needs to be carefully considered when evaluating and predicting subsurface As mobility in the presence of sulphidisation.

\subsection{Iron Oxidation}

Due to the high adsorption capacity to As, the formation of Fe(III) (hydr)oxides is undoubtedly capable of trapping As from the solution phases. Microorganismmediated Fe(III) (hydr)oxide is known to be responsible for As immobilisation in acid mine drainage (see also Section 4.6) (Duquesne et al. 2003; Ma and Lin 2012) and the presence of free $\mathrm{Fe}^{3+}$ ion enable to oxidise As(III) to As(V) abiotically (Huang and Kretzschmar 2010). Furthermore, microbial Fe oxidation has been broadly applied for As remediation in anoxic environments (Hohmann et al. 2010; Kleinert et al. 2011; Liu et al. 2013a). Different from the abiotic Fe(III) (hydr)oxides, the presence of cell organic matter in biogenic Fe(III) (hydr)oxides seems to decrease As adsorption capacity, probably due to competitive adsorption (Hohmann et al. 2011; Kleinert et al. 2011).

\subsection{Bioleaching}

Arsenic bioleaching is usually referred to as biooxidation of As containing sulphide minerals, e.g. arsenopyrite (FeAsS), enargite $\left(\mathrm{Cu}_{3} \mathrm{AsS}_{4}\right)$ and realgar $\left(\mathrm{As}_{4} \mathrm{~S}_{4}\right)$ by acidophilic $\mathrm{Fe}$ oxidation microorganisms such as A. ferrooxidans, Leptospirillum ferrooxidans, Thiobacillus ferrooxidans and Thiobacillus caldus (Acevedo et al. 1998; Corkhill et al. 2008; Dopson and Lindstrom 1999; Marquez et al. 2012). Usually, bioleaching is more efficient than abiotic oxidation (Corkhill et al. 2008). Bioleaching of As-containing sulphide minerals usually occurs via the microbial transformation of ferrous to ferric ions with the subsequent chemical oxidation of sulphides by $\mathrm{Fe}^{3+}$ (Marquez et al. 
2012). It has been indicated that a close contact between microorganisms and the mineral is needed for leaching (Arredondo et al. 1994). Thus, the $\mathrm{Fe}^{3+}$ produced may also become a constitute of extracellular polymeric substances supporting microbial attachment to mineral surface and the biooxidation process. The presence of microorganism such as $T$. caldus may support bioleaching by metabolise $S^{0}$ built upon the surface of the mineral, allowing microbial and chemical access to the mineral (Dopson and Lindstrom 1999). Another potential pathway is the microbial oxidation of sulphides parallel releasing As(III) in solution (Chen et al. 2011). Some microorganisms, like $A$. ferrooxidans, are able to oxidise As(III) to As(V) and thereby decrease As mobility (Zhang et al. 2007). Additionally, the oxidation of $\mathrm{As}(\mathrm{III})$ to $\mathrm{As}(\mathrm{V})$ could be catalysed by microbial oxidising $\mathrm{Fe}^{2+}$ presented to conserve energy (Chen et al. 2011). Bioleaching may elevate As concentrations in solution up to several grams per litre (Acevedo et al. 1998). On the other hand, the release of As may be suppressed by formation of the secondary mineral precipitates such as jarosite $\left[\mathrm{KFe}_{3}(\mathrm{OH})_{6}\left(\mathrm{SO}_{4}\right)_{2}\right]$, magnetite $\left(\mathrm{Fe}_{3} \mathrm{O}_{4}\right)$, ferric arsenate $\left[\mathrm{Fe}_{2}\left(\mathrm{AsO}_{4}\right)_{3}\right]$, scorodite $\left(\mathrm{FeAsO}_{4} \cdot 2 \mathrm{H}_{2} \mathrm{O}\right)$, schwertmannite $\left[\mathrm{Fe}_{8} \mathrm{O}_{8}(\mathrm{OH})_{6}\left(\mathrm{SO}_{4}\right)\right.$. $\left.\mathrm{nH}_{2} \mathrm{O}\right]$, ferric hydroxide $\left[\mathrm{Fe}(\mathrm{OH})_{3}\right]$ and ferric phosphate $\left[\mathrm{Fe}_{2}\left(\mathrm{PO}_{4}\right)_{3}\right]$ (Chen et al. 2011; Corkhill et al. 2008; Duquesne et al. 2003). Arsenolite $\left(\mathrm{As}_{2} \mathrm{O}_{3}\right)$ may also be created during bioleaching of arsenopyrite. Although it is highly water soluble, this presents as fine particles embedded in the jarosite matrix, which prevents its dissolution (Marquez et al. 2012). Therefore, the mobility of As after bioleaching seems to be determined by the environmental matrix. For example, bioleaching of realgar with $A$. ferrooxidans by adding $\mathrm{Fe}^{2+}$ led to the formation of jarosite, whereas adding sulphur and $\mathrm{Fe}^{2+}$ suppressed the formation of jarosite (Chen et al. 2011). The presence of highly concentrated $\mathrm{As}(\mathrm{III})$ and $\mathrm{As}(\mathrm{V})$ inhibited bioleaching due to the toxic effect (Breed et al. 1996).

\section{Influence of Microbial Redox Transformation on Arsenic Mobility in Natural Soils and Sediments}

Few attempts were made to outline the influence of microbial activities on As mobilisation from soils and sediments by inoculating pure cultures. For example, inoculating a native $\mathrm{As}(\mathrm{V})$-reducing strain MIT-13 in the sediment of the Aberjona watershed demonstrated the potential of microbial $\mathrm{As}(\mathrm{V})$ reduction to release As associated with sediment solids (Ahmann et al. 1997). Incubations of lake sediments with Shewanella alga BrY demonstrated Fe(III) reduction releasing As(V) without reducing it (Cummings et al., 1999). The latest studies with Fe(III) reducing Shewanella strains of different $\mathrm{As}(\mathrm{V})$ reducing activities showed very different As mobilisation behaviour from ferrihydrite and natural soils. In the incubations with ferrihydrite, As mobilisation was only observed in the incubation with the strain capable of $\mathrm{As}(\mathrm{V})$ reduction, whereas As release from the natural soils was detected in all incubations. Such discrepancy suggests that the soil matrix substantially changed the geochemical behaviour of As and $\mathrm{Fe}$ species and, furthermore, to implicate the knowledge obtained from the model experiments to the natural system, it is indispensable to include the effects caused by the matrix from the natural samples, which much more focus should be placed on in the future research.

\section{Arsenic Mobilisation and Immobilisation via Non-redox Reaction-Induced Mineral Dissolution and Precipitation}

\subsection{Mineral Dissolution}

Microorganisms have developed several different strategies to dissolve insoluble minerals to obtain the nutrients encompassed. The most well-known case is probably the production of siderophores, which are small, high-affinity Fe-chelating compounds secreted by microorganisms (Gadd 2004). In addition to Fe, siderophores can also bind to the other metals such as $\mathrm{Al}, \mathrm{Mn}, \mathrm{Mg}, \mathrm{Cr}$, etc. Different from reductive dissolution of $\mathrm{Fe}(\mathrm{III})$ (hydr)oxides, the complexation of $\mathrm{Fe}^{3+}$ retards the formation of secondary minerals and As solubilisation is thus plausible. Pseudomonads strains isolated from mining sites produced siderophores, which could promote mineral dissolution and mobilisation of the more toxic As(III) species in the environment (Matlakowska et al. 2008). Nair et al. (2007) indicated that the siderophore secreted by Pseudomonas azotoformans is capable of complexation with $\mathrm{As}(\mathrm{III})$ and $\mathrm{As}(\mathrm{V})$ and thereby extracted not only the bioavailable fraction but also bound As in soils. Mineral dissolution may also occur via the by-product of microbial metabolites. Phosphate-limited cells of Burkholderia fungorum mobilise ancillary As from 
apatite as a by-product of mineral weathering for nutrient acquisition (Mailloux et al. 2009). Microbial oxidative degradation of glucose to gluconic acid by $B$. fungorum in intimate contact with apatite $\left(\mathrm{Ca}_{5}\left(\mathrm{PO}_{4}\right)_{3}(\mathrm{~F}, \mathrm{Cl}, \mathrm{OH})\right)$ is a likely cause of As release from the mineral structure into the water. In the absence of secondary precipitates, the mobility of As in this case will simply be determined by the amount and adsorption capacity of the compounds. Microorganisms may also secrete organic compounds for other purposes; e.g. Shewanella spp. are able to produce Fe(III) solubilising ligands to initialise respiration of insoluble Fe(III) (hydr)oxides (Taillefert et al., 2007). There may be more mechanisms of As mobilisation via microorganisminduced mineral dissolution, but these have not yet been identified. For instance, Frey et al.(2010) highlighted the potential of $\mathrm{HCN}$-producing microorganisms to dissolve minerals, which might be a probable mechanism to release mineral-associated As. Therefore, microorganisms seem to be more involved, directly or indirectly, in mineral dissolution-induced As release than we currently know, which might be a potential focus of future research.

\subsection{Biomineralisation}

Aside from the influence of biogenic Fe, Mn and sulphide minerals (see also Fe reduction and oxidation and sulphidisation), a range of biogenic minerals may immobilise As in solution. For example, calcite precipitated by the As(III) tolerant soil bacterium Sporosarcina ginsengisoli CR5 was able to shift soil As from the exchangeable fraction to the carbonated fraction (Achal et al. 2012). Another biomineralisation process to immobilise As is the formation of As precipitates, e.g. scorodite and As sulphide (see bioleaching and sulphidisation). There are more than 300 As minerals known to occur in nature (Drahota and Filippi 2009). For example, in an As-contaminated perched aquifer affected by mining activity, free $\mathrm{Ca}^{2+}$ availability was found to control As mobility in the aquifer through the diagenetic precipitation of calcium arsenates $\left[\mathrm{Ca}_{5} \mathrm{H}_{2}\left(\mathrm{AsO}_{4}\right)_{4} \cdot \mathrm{cH}_{2} \mathrm{O}\right]$ preventing further mobilisation of As in Ca-rich environments (Martinez-Villegas et al. 2013). For decades, it has been a common practice to stabilise As wastes as metal arsenate compounds (i.e. ferric arsenate, calcium arsenate and magnesium arsenate) (Bothe and Brown 1999; McNeill and Edwards 1997), and to dispose of them in slags, tailings and residue dumps (Robins 1981). The significance, mechanism and environmental implication of many microbial minerals have been reviewed (Benzerara et al. 2011). In comparison, the occurrence of most microbial As minerals is still not clear.

\section{Biofilm}

Most microorganisms can form biofilms, and over $99 \%$ of all microorganisms on earth live in these biological structures (Costerton et al. 1987). Biofilms allow the coexistence of microniches of different physiological requirements, enabling the simultaneous, but spatially separated occurrence of opposing redox processes in the same biofilm environment (Labrenz et al. 2000; van Hullebusch et al. 2003). This important role of biofilm in As biogeochemistry was evidenced by the potential enrichment of As in biofilm. The concentrations of As in rock biofilm reached up to $60 \mathrm{mg} \mathrm{kg}^{-1}$ (dry weight) (Drewniak et al. 2008). A recent research based on Xray absorption spectroscopic analysis focussed on As biotransformation in the mix cultured biofilm spiked with 50-1,000 ppm As(III) and As(V) (Yang et al. 2011). Interestingly, there might be simultaneous As oxidation and reduction in biofilms, although the extent of As(III) oxidation was apparently higher than that of $\mathrm{As}(\mathrm{V})$ reduction. Aside from As redox transformation, As methylation was also indicated, as shown by the appearance of monomethylarsonous acid and trimethylarsine oxide after 20 and 90 days of incubation. The addition of Se seemed to stimulate As redox transformation and methylation in biofilms. The oxidation of As(III) and the formation of trimethylarsine oxide was especially suggested as a useful application of the aforementioned biofilm for As(III) removal and detoxification in $\mathrm{As}(\mathrm{III})$ contaminated aquatic environments. It has also been demonstrated that As treatment can lead to changes in microbial biofilm structure. Another study concerning rock biofilm from an ancient gold and As mine highlighted the simultaneous presence of Asoxidising and As-reducing bacteria and evidenced the ability of siderophores in biofilm porewater to mobilise As from the rock (arsenopyrite) (Tomczyk-Żak et al. 2013). Still, the knowledge concerning biofilm As is scant. Further research on As-biofilm interactions and biofilm As transformations is required in the future with the objective of defining the role of biofilms in As biogeochemistry. 


\section{Conclusion and Outlook}

The past research has clearly indicated the significant influence of microorganisms on the environmental fate and transport of As, regardless of whether the contribution is direct or indirect. Figure 1 summarises the potential pathways of the direct interactions between microbial cells and As, including physical sequestration and chemical transformation. Accordingly, taking the soil as an example, in which the microbial density may reach up to $10^{10}$ cells g $^{-1}$ (Torsvik et al. 2002), the presence of microbial cells in the environmental media may already change As adsorption affinity to mineral surfaces due to the cell surface functional group competition, intracellular sequestration and cell surface biosorption. Microbial transformation of As, Fe, S and Mn simultaneously affects the mobility of As in nature, while the mobility of As depends largely on the chemical forms of As Fe, S and $\mathrm{Mn}$. Therefore, biotransformation could be considered the major driving force of the As biogeochemical cycle. Table 3 outlines the influence of different microbial processes on As mobility at the water-mineral interface. The influence of microbial processes acting directly on As can be clearly concluded. For example, As reduction and methylation increase the mobility of As, whereas oxidation and demethylation decrease As mobility. In comparison, for those processes indirectly associated with As such as $\mathrm{Fe}$ and $\mathrm{S}$ redox transformation, their influence on As environmental mobility is usually ambiguous. As indicated in the schematic presentation of the interaction among $\mathrm{Fe}, \mathrm{S}$ and As redox cycling (Fig. 2), which was proposed based on the literature information, the interplay between $\mathrm{Fe}$ and $\mathrm{S}$ redox transformation and As biogeochemical behaviour is complicated. Iron and $\mathrm{S}$ redox transformation may cause the precipitation of secondary minerals [e.g. Fe(II) and $\mathrm{Fe}$ (III) (hydr)oxides, $\mathrm{FeAsO}_{4}, \mathrm{FeS}, \mathrm{As}_{2} \mathrm{~S}_{3}$ ] for trapping As in solution. On the other hand, they may mobilise As via the reductive dissolution of Fe(III) hydroxides, oxidation of As-containing sulphides and the formation of dissolved thioarsenic complexes. Additionally, their redox products $\left(\mathrm{S}^{2-}\right.$ and free $\left.\mathrm{Fe}^{3+}\right)$ are able to induce abiotic As redox transformation. Apparently, the mobility of As is governed by whether the formation of secondary minerals takes place or not. In addition, the interplay between $\mathrm{Fe}$ and $\mathrm{S}$ redox transformation shifts the extent of their influence on As mobilisation. For example, the presence of much larger amounts of Fe(III) hydroxides in soils and sediments inhibit the interaction between S redox cycling with As (Kocar et al. 2010).

The soil matrix has been shown to be capable of completely changing the mobility of As associated with
Table 3 Summary of microbial processes influencing arsenic mobility in the surface environment

\begin{tabular}{|c|c|}
\hline Processes & Comments \\
\hline \multicolumn{2}{|l|}{ Mobilisation } \\
\hline Arsenic reduction & As(III) more mobile than As(V) \\
\hline Arsenic methylation & (Gaseous) Methyl As mobile than inorganic As \\
\hline \multicolumn{2}{|l|}{ Competitive adsorption } \\
\hline \multicolumn{2}{|l|}{ Immobilisation } \\
\hline Arsenic oxidation & As(III) more mobile than As(V) \\
\hline Demethylation & (Gaseous) Methyl As more mobile than inorganic As \\
\hline Biomineralisation & Adsorption and formation of As containing minerals \\
\hline Biosorption & Extracellular sequestration \\
\hline Bioaccumulation & Intracellular sequestration \\
\hline Iron oxidation & Formation of Fe(III) (hydr)oxide for As sorption \\
\hline \multicolumn{2}{|c|}{ Mobilisation and immobilisation } \\
\hline \multirow[t]{2}{*}{ Iron reduction } & Mobilisation: reductive dissolution of Fe (hydr)oxide \\
\hline & Immobilisation: secondary mineral sequestration \\
\hline \multirow[t]{2}{*}{ Sulphidisation } & Mobilisation: formation of aqueous As-S complexes \\
\hline & Immobilisation: formation of As sulphide precipitates \\
\hline \multirow[t]{2}{*}{ Bioleaching } & Mobilisation: oxidative dissolution \\
\hline & Immobilisation: secondary mineral sequestration \\
\hline
\end{tabular}


Table 4 Microorganism based arsenic bioremediation proposed in the literature to date

Biosorption

- Fe(III) treated Baccilus subtulis has 11 times higher $\mathrm{As}(\mathrm{V})$ sorption capacity than that of the native bacteria

- The maximum biosorption capacity of living cells of Bacillus cereus for As(III) was found to be $32.42 \mathrm{mg} \mathrm{g}^{-1}$ at $\mathrm{pH} 7.5$, at optimum conditions of contact time of $30 \mathrm{~min}$, biomass dosage of $6 \mathrm{~g} \mathrm{~L}^{-1}$, and temperature of $30{ }^{\circ} \mathrm{C}$

- Bacillus cereus Strain W2 retained As(III) and As(V) up to $1.87 \mathrm{mg} \mathrm{As} \mathrm{g}^{-1}$ of dry cell weight and dry cell removal capacity up to $0.18 \mathrm{mg} \mathrm{As} \mathrm{g}^{-1}$

- The biosorption capacity of the Rhodococcus sp. WB-12 for As(III) was $77.3 \mathrm{mg} \mathrm{g}^{-1}$ at $\mathrm{pH} 7.0 \mathrm{using} 1 \mathrm{~g}$ $\mathrm{L}^{-1}$ biomass with the contact time of $30 \mathrm{~min}$ at $30^{\circ} \mathrm{C}$

Bioaccumulation

- Engineering of phytochelatin producing, As transporter GlpF co-expressing and an As efflux deletion Escherichia coli showed a 80-fold more As accumulation than a control strain, achieving accumulation level of $16.8 \mu \mathrm{mol} \mathrm{g}^{-1}$ (dry cell weight)

- Saccharomyces cerevisiae was engineered for 3-4-fold greater As(III) uptake and accumulation by overexpression of transporters genes FPS1 and HXT7 responsible for the influx of the contaminant coupled with and without high-level production of cytosolic As sequestors (phytochelatins or bacterial ArsRp)

- Engineered Escherichia coli expressing ArsR accumulated 50-60 times higher As(III) and As(V) than control

(Yang et al. 2012)

(Giri et al. 2013)

Bioreduction

- The co-presence of anthraquinone-2,6-disulfonate with $\mathrm{As}(\mathrm{V})$ respiratory reducing bacteria (Bacillus selenatarsenatis SF-1) improved the removal efficiency and can be an effective strategy for remediation of As-contaminated soils

Biomethylation

- A synergistic degradation system combining two bacteria (Bacillus sp. PY1 and Sphingomonas sp. PY2) and a fungus (Fusarium sp. PY3), isolated from contaminated soils is the most effective approach to degrade pyrene and remove As in contaminated soil

- Engineering the soil bacterium Pseudomonas putida expressing the As(III) S-adenosylmethionine

(Miyatake and Hayashi 2011)

(Prasad et al. 2011)

(Singh et al. 2010)

(Shah et al. 2010)

(Kostal et al. 2004)

(Yamamura et al. 2008) methyltransferase gene has the potential for bioremediation of environmental As

- Soil microorganism e.g. Trichoderma sp., sterile mycelial strain, Neocosmospora sp. and Rhizopus sp. fungal (Srivastava et al. 2011) strains could be used for soil As bioremediation via biovolatilisation

Biomineralisation

- The nitrate- and sulphate-plus-lactate-amended microcosms with sediment from an aquifer with naturally elevated As levels decreased effective soluble As levels from 3.9 to 0.01 and $0.41 \mu \mathrm{M}$ via sorption onto freshly formed hydrous ferric oxide and iron sulphide

- The biogenic Mn oxides generated by Marinobacter sp. MnI7-9 oxidised the highly toxic As(III) to As(V) and decreased the concentration of As(III) from 55.02 to $5.55 \mu \mathrm{M}$

- Arsenic immobilisation by biogenic Fe-mineral formed by Acidovorax sp. BoFeN1, an anaerobic nitrate-reducing Fe(II)-oxidising ß-proteobacteria

- Microbial calcite precipitated by an As(III) tolerant bacterium Sporosarcina ginsengisoli CR5 to retain As

- Bioremediation strategy based on injecting nitrate to support the anoxic oxidation of Fe(II) and As(III) in the subsurface as a means to immobilise As in the form of $\mathrm{As}(\mathrm{V})$ adsorbed onto biogenic Fe(III) (hydr)oxides

(Omoregie et al. 2013)

(Liao et al. 2013)

(Hitchcock et al. 2012)

(Achal et al. 2012)

(Sun et al. 2009)

Fe (hydr)oxide during microbial Fe(III) reduction (Jiang et al. 2013). Thus, many natural substances are expected to exhibit substantial effects on the microbial processes and subsequently change the environmental behaviour of As, either directly or indirectly. One of the best known examples is natural organic matter. Although its presence may partly explain the controversial findings of $\mathrm{Fe}(\mathrm{III})$ reduction-induced As releases between lab model studies and field work in the past (Davranche et al. 2013), natural organic matter may also interact with As by (1) serving as an electron donor or carbon source to fuel Fe(III) and As(III) reduction (Lovley et al. 1996) and methylation (Zheng et al. 2013), (2) as an adsorbant to complete As adsorption to the mineral surface (Weng et al. 2009), (3) as a sorbent for As (Thanabalasingam and Pickering 1986) and (4) as an abiotic reductant for As(V) (Palmer and von Wandruszka 2010). This highlights the fact that there are still many unknown factors influencing As fate and mobility in the environment and, at the same time, that the research concerning microbial As is still in its infancy; 
therefore, a thorough understanding the true As behaviour in the surface and subsurface environments under the influence of microbial activities is still very challenging.

Researching microorganism-As interactions also provides the opportunity of studying As remediation taking advantage of microbial activities (Wang and Zhao 2009). More and more studies have shown the potential to utilise (genetic engineered) microorganisms to remediate As-contaminated compartments e.g. via bioreduction (Yamamura et al. 2008), biomethylation (Chen et al. 2013; Liu et al. 2013b; Srivastava et al. 2011), biomineralisation (Achal et al. 2012; Hitchcock et al. 2012; Liao et al. 2013; Omoregie et al. 2013; Sun et al. 2009), biosorption (Giri et al. 2013; Miyatake and Hayashi 2011; Prasad et al. 2011; Yang et al. 2012) or bioaccumulation (Kostal et al. 2004; Shah et al. 2010; Singh et al. 2010). Information from some recent publications about As remediation utilising microorganisms is outlined in Table 4. Although microbial transformation may help to release solid-associated As into the gaseous or aqueous phases, no suggestion was given for the follow-up removal/treatment of mobilised As. In comparison, research into As remediation based on intra- and extra-cellular sequestration seems to be deeper. The cell retention capacity of As was largely magnified by manipulating phytochelatin producing, As transporter and As efflux genes (Singh et al. 2010) and overexpressing As-resistance regulatory proteins (Kostal et al. 2004). Although it is very difficult to have an objective comparison of the retention capacity among different methods due to inconsistencies of the experimental conditions, the proposed microorganism-based methods for As removal based on intra- and extracellular sequestration still seem to be unsatisfactory compared to the conventional abiotic methods. Currently, the retention capacity of Rhodococcus sp. WB-12 cells is the highest of all microorganisms in the literature, with a value of $77.3 \mathrm{mg} \mathrm{g}^{-1}$ for As(III) at pH 7.0 (Prasad et al. 2011) (Table 4). However, this is far from the adsorption capacity of minerals (e.g. $300-375 \mathrm{mg} \mathrm{g}^{-1}$ to hydrous ferric oxide) (Raven et al. 1998) and $1,125 \mathrm{mg} \mathrm{g}^{-1}$ to amorphous $\mathrm{Al}(\mathrm{OH})_{3}$ (Anderson et al., 1976). The microorganism-based treatment is usually advantageous over minerals due to lower costs of treatment (Wang and Zhao 2009). Thus, more extensive and deeper research into As-microorganismmineral interactions may help to identify the appropriate conditions for improving the efficiency of microbial As remediation, making it comparable with abiotic methods.

Acknowledgements This work was financially supported by Swiss National Science Foundation (PZ00P2_142232).

\section{Appendix 1}

Table 5 Minerals and their chemical formulas mentioned in this review

\begin{tabular}{|c|c|}
\hline Mineral & Chemical formula \\
\hline Apatite & $\mathrm{Ca}_{5}\left(\mathrm{PO}_{4}\right)_{3}(\mathrm{~F}, \mathrm{Cl}, \mathrm{OH})$ \\
\hline Arsenolite & $\mathrm{As}_{2} \mathrm{O}_{3}$ \\
\hline Arsenopyrote & FeAsS \\
\hline $\mathrm{Pb}$-As Jarosite & $\mathrm{PbFe}_{3}\left(\mathrm{SO}_{4}, \mathrm{AsO}_{4}\right)_{2}(\mathrm{OH})_{6}$ \\
\hline Birnessite & $\mathrm{MnO}_{2}$ \\
\hline Bobierrite & $\mathrm{Mg}_{3}\left(\mathrm{PO}_{4}\right)_{2} \cdot 8 \mathrm{H}_{2} \mathrm{O}$ \\
\hline Boehmite & $\gamma$-AlOOH \\
\hline Calcite & $\mathrm{CaCO}_{3}$ \\
\hline Calcium arsenates & $\left(\mathrm{Ca}_{5} \mathrm{H}_{2}\left(\mathrm{AsO}_{4}\right)_{4} \cdot \mathrm{cH}_{2} \mathrm{O}\right.$ \\
\hline Enargite & $\mathrm{Cu}_{3} \mathrm{AsS}_{4}$ \\
\hline Ferrihydrite & $\mathrm{Fe}_{5} \mathrm{HO}_{8} \cdot 4 \mathrm{H}_{2} \mathrm{O}$ \\
\hline Goethite & $\alpha-\mathrm{FeO}(\mathrm{OH})$ \\
\hline Green rust & {$\left[\mathrm{Fe}_{(1-x)}^{\mathrm{II}} \mathrm{Fe}_{x}{ }^{\mathrm{III}}(\mathrm{OH})_{2}\right]^{x+} \cdot\left[(x / n) A^{n-} \cdot(m / n) \mathrm{H}_{2} \mathrm{O}\right]^{x}$} \\
\hline Hematite & $\alpha-\mathrm{Fe}_{2} \mathrm{O}_{3}$ \\
\hline Iron sulphide & $\mathrm{FeS}$ \\
\hline Jarosite & $\mathrm{KFe}_{3}(\mathrm{OH})_{6}\left(\mathrm{SO}_{4}\right)_{2}$ \\
\hline Mackinawite & $\mathrm{FeS}$ \\
\hline Magnetite & $\mathrm{Fe}_{3} \mathrm{O}_{4}$ \\
\hline Orpiment & $\mathrm{As}_{2} \mathrm{~S}_{3}$ \\
\hline Realgar & $\mathrm{As}_{4} \mathrm{~S}_{4}$ \\
\hline Rhodochrosite & $\mathrm{MnCO}_{3}$ \\
\hline Schwertmannite & $\left(\mathrm{Fe}_{8} \mathrm{O}_{8}(\mathrm{OH})_{6}\left(\mathrm{SO}_{4}\right) \cdot n \mathrm{H}_{2} \mathrm{O}\right)$ \\
\hline Scorodite & $\mathrm{FeAsO}_{4} \cdot 2 \mathrm{H}_{2} \mathrm{O}$ \\
\hline
\end{tabular}

\section{References}

Abedin, M. J., Feldmann, J., \& Meharg, A. A. (2002). Uptake kinetics of arsenic species in rice plants. Plant Physiology, 128(3), 1120-1128.

Acevedo, F., Gentina, J. C., \& Garcia, N. (1998). $\mathrm{CO}_{2}$ supply in the biooxidation of an enargite-pyrite gold concentrate. Biotechnology Letters, 20(3), 257-259. 
Achal, V., Pan, X. L., Fu, Q. L., \& Zhang, D. Y. (2012). Biomineralization based remediation of As(III) contaminated soil by Sporosarcina ginsengisoli. Journal of Hazardous Materials, 201, 178-184.

Ahmann, D., Krumholz, L. R., Hemond, H. F., Lovley, D. R., \& Morel, F. M. M. (1997). Microbial mobilization of arsenic from sediments of the Aberjona Watershed. Environmental Science \& Technology, 31(10), 2923-2930.

Ajith, N., Dalvi, A. A., Swain, K. K., Devi, P. S. R., Kalekar, B. B., Verma, R., \& Reddy, A. V. R. (2013). Sorption of As(III) and $\mathrm{As}(\mathrm{V})$ on chemically synthesized manganese dioxide. Journal of Environmental Science and Health Part AToxic/Hazardous Substances \& Environmental Engineering, 48(4), 422-428.

Amstaetter, K., Borch, T., Larese-Casanova, P., \& Kappler, A. (2010). Redox transformation of arsenic by Fe(II)-activated goethite (alpha-FeOOH). Environmental Science \& Technology, 44(1), 102-108.

Anderson, M. A., Ferguson, J. F., \& Gavis, J. (1976). Arsenate adsorption on amorphous aluminum hydroxide. Journal of Colloid and Interface Science, 54(3), 391-399.

Arredondo, R., Garcia, A., \& Jerez, C. A. (1994). Partial removal of lipopolysaccharide from Thiobacillus ferrooxidans affects its adhesion to solids. Applied and Environmental Microbiology, 60(8), 2846-2851.

Babechuk, M. G., Weisener, C. G., Fryer, B. J., Paktunc, D., \& Maunders, C. (2009). Microbial reduction of ferrous arsenate: Biogeochemical implications for arsenic mobilization. Applied Geochemistry, 24(12), 2332-2341.

Bennett, W. W., Teasdale, P. R., Panther, J. G., Welsh, D. T., Zhao, H. J., \& Jolley, D. F. (2012). Investigating arsenic speciation and mobilization in sediments with DGT and DET: A mesocosm evaluation of oxic-anoxic transitions. Environmental Science \& Technology, 46(7), 3981-3989.

Benzerara, K., Miot, J., Morin, G., Ona-Nguema, G., SkouriPanet, F., \& Ferard, C. (2011). Significance, mechanisms and environmental implications of microbial biomineralization. Comptes Rendus Geoscience, 343(2-3), 160-167.

Bissen, M., \& Frimmel, F. H. (2003). Arsenic-A review. Part 1: Occurrence, toxicity, speciation, mobility. Acta Hydrochimica Et Hydrobiologica, 31(1), 9-18.

Blodau, C., Fulda, B., Bauer, M., \& Knorr, K. H. (2008). Arsenic speciation and turnover in intact organic soil mesocosms during experimental drought and rewetting. Geochimica et Cosmochimica Acta, 72(16), 3991-4007.

Bothe, J. V., \& Brown, P. W. (1999). Arsenic immobilization by calcium arsenate formation. Environmental Science \& Technology, 33(21), 3806-3811.

Breed, A. W., Glatz, A., Hansford, G. S., \& Harrison, S. T. L. (1996). The effect of As(III) and As(V) on the batch bioleaching of a pyrite-arsenopyrite concentrate. Minerals Engineering, 9(12), 1235-1252.

Bundschuh, J., Litter, M. I., Parvez, F., Roman-Ross, G., Nicolli, H. B., Jean, J. S., Liu, C. W., Lopez, D., Armienta, M. A., Guilherme, L. R. G., Cuevas, A. G., Cornejo, L., Cumbal, L., \& Toujaguez, R. (2012). One century of arsenic exposure in Latin America: A review of history and occurrence from 14 countries. Science of the Total Environment, 429, 2-35.

Burnol, A., Garrido, F., Baranger, P., Joulian, C., Dictor, M. C., Bodenan, F., Morin, G., \& Charlet, L. (2007). Decoupling of arsenic and iron release from ferrihydrite suspension under reducing conditions: A biogeochemical model. Geochemical Transactions, 8.

Burton, E. D., Johnston, S. G., \& Bush, R. T. (2011). Microbial sulfidogenesis in ferrihydrite-rich environments: Effects on iron mineralogy and arsenic mobility. Geochimica et Cosmochimica Acta, 75(11), 3072-3087.

Burton, E. D., Johnston, S. G., \& Planer-Friedrich, B. (2013). Coupling of arsenic mobility to sulfur transformations during microbial sulfate reduction in the presence and absence of humic acid. Chemical Geology, 343, 12-24.

Campbell, K. M., Malasarn, D., Saltikov, C. W., Newman, D. K., \& Hering, J. G. (2006). Simultaneous microbial reduction of iron(III) and arsenic(V) in suspensions of hydrous ferric oxide. Environmental Science \& Technology, 40(19), 5950-5955.

Cantor, K. P. (1996). Arsenic in drinking water: How much is too much? Epidemiology, 7(2), 113-115.

Cavalca, L., Corsini, A., Zaccheo, P., Andreoni, V., \& Muyzer, G. (2013). Microbial transformations of arsenic: Perspectives for biological removal of arsenic from water. Future Microbiology, 8(6), 753-768.

Cervantes, C., Ji, G. Y., Ramirez, J. L., \& Silver, S. (1994). Resistance to arsenic compounds in microorganisms. FEMS Microbiology Reviews, 15(4), 355-367.

Chandraprabha, M. N., \& Natarajan, K. A. (2011). Mechanism of arsenic tolerance and bioremoval of arsenic by Acidithiobacilus ferrooxidans. Journal of Biochemical Technology, 3, 257-265.

Chen, P., Yan, L., Leng, F. F., Nan, W. B., Yue, X. X., Zheng, Y. N., Feng, N., \& Li, H. Y. (2011). Bioleaching of realgar by Acidithiobacillus ferrooxidans using ferrous iron and elemental sulfur as the sole and mixed energy sources. Bioresource Technology, 102(3), 3260-3267.

Chen, J., Qin, J., Zhu, Y.-G., de Lorenzo, V., \& Rosen, B. P. (2013). Engineering the soil bacterium Pseudomonas putida for arsenic methylation. Applied and Environmental Microbiology, 79(14), 4493-4495.

Chilvers, D. C. \& Peterson, P. J. (1987). Global cycling of arsenic. in T. C. Hutchinson \& K. M. Meema (Eds.), Lead, mercury, cadmium and arsenic in the environment (pp. 279-301). New York: Wiley.

Coker, V. S., Gault, A. G., Pearce, C. I., van der Laan, G., Telling, N. D., Charnock, J. M., Polya, D. A., \& Lloyd, J. R. (2006). XAS and XMCD evidence for species-dependent partitioning of arsenic during microbial reduction of ferrihydrite to magnetite. Environmental Science \& Technology, 40(24), 7745-7750.

Corkhill, C. L., Wincott, P. L., Lloyd, J. R., \& Vaughan, D. J. (2008). The oxidative dissolution of arsenopyrite (FeAsS) and enargite $\left(\mathrm{Cu}_{3} \mathrm{AsS}_{4}\right)$ by Leptospirillum ferrooxidans. Geochimica et Cosmochimica Acta, 72(23), 5616-5633.

Corsini, A., Cavalca, L., Crippa, L., Zaccheo, P., \& Andreoni, V. (2010). Impact of glucose on microbial community of a soil containing pyrite cinders: Role of bacteria in arsenic mobilization under submerged condition. Soil Biology \& Biochemistry, 42(5), 699-707.

Costerton, J. W., Cheng, K. J., Geesey, G. G., Ladd, T. I., Nickel, J. C., Dasgupta, M., \& Marrie, T. J. (1987). Bacterial biofilms in nature and disease. Annual Review of Microbiology, 41, 435-464.

Cullen, W. R., \& Reimer, K. J. (1989). Arsenic speciation in the environment. Chemical Reviews, 89(4), 713-764. 
Cullen, W. R., Li, H., Hewitt, G., Reimer, K. J., \& Zalunardo, N. (1994). Identification of extracellular arsenical metabolites in the growth-medium of the microorganisms Apiotrichum humicola and Scopulariopsis brevicaulis. Applied Organometallic Chemistry, 8(4), 303-311.

Cummings, D. E., Caccavo, F., Fendorf, S., \& Rosenzweig, R. F. (1999). Arsenic mobilization by the dissimilatory Fe(III)reducing bacterium Shewanella alga BrY. Environmental Science \& Technology, 33(5), 723-729.

Cutting, R. S., Coker, V. S., Telling, N. D., Kimber, R. L., van der Laan, G., Pattrick, R. A. D., Vaughan, D. J., Arenholz, E., \& Lloydt, J. R. (2012). Microbial reduction of arsenic-doped schwertmannite by Geobacter sulfurreducens. Environmental Science \& Technology, 46(22), 12591-12599.

Davranche, M., Dia, A., Fakih, M., Nowack, B., Gruau, G., OnaNguema, G., Petitjean, P., Martin, S., \& Hochreutener, R. (2013). Organic matter control on the reactivity of Fe(III)oxyhydroxides and associated As in wetland soils: A kinetic modeling study. Chemical Geology, 335, 24-35.

Demergasso, C. S., Chong, G., Escudero, L., Mur, J. J. P., \& Pedros-Alio, C. (2007). Microbial precipitation of arsenic sulfides in Andean salt flats. Geomicrobiology Journal, 24(2), 111-123.

Dhuldhaj, U. P., Yadav, I. C., Singh, S., \& Sharma, N. K. (2013). Microbial interactions in the arsenic cycle: Adoptive strategies and applications in environmental management. In D. M. Whitacre (Ed.), Reviews of Environmental Contamination and Toxicology (Vol. 224, pp. 1-38). New York: Springer.

Dixit, S., \& Hering, J. G. (2003). Comparison of arsenic(V) and arsenic(III) sorption onto iron oxide minerals: Implications for arsenic mobility. Environmental Science \& Technology, $37(18), 4182-4189$.

Dong, H. L. (2010). Mineral-microbe interactions: A review. Frontiers of Earth Science, 4(2), 127-147.

Dopson, M., \& Lindstrom, E. B. (1999). Potential role of Thiobacillus caldus in arsenopyrite bioleaching. Applied and Environmental Microbiology, 65(1), 36-40.

Dowdle, P. R., Laverman, A. M., \& Oremland, R. S. (1996). Bacterial dissimilatory reduction of $\operatorname{arsenic}(\mathrm{V})$ to arsenic(III) in anoxic sediments. Applied and Environmental Microbiology, 62(5), 1664-1669.

Drahota, P., \& Filippi, M. (2009). Secondary arsenic minerals in the environment: A review. Environment International, 35(8), 1243-1255.

Drewniak, L., Styczek, A., Majder-Lopatka, M., \& Sklodowska, A. (2008). Bacteria, hypertolerant to arsenic in the rocks of an ancient gold mine, and their potential role in dissemination of arsenic pollution. Environmental Pollution, 156(3), 1069-1074.

Du Laing, G., Chapagain, S. K., Dewispelaere, M., Meers, E., Kazama, F., Tack, F. M. G., Rinklebe, J., \& Verloo, M. G. (2009). Presence and mobility of arsenic in estuarine wetland soils of the Scheldt estuary (Belgium). Journal of Environmental Monitoring, 11(4), 873-881.

Duquesne, K., Lebrun, S., Casiot, C., Bruneel, O., Personne, J. C., Leblanc, M., Elbaz-Poulichet, F., Morin, G., \& Bonnefoy, V. (2003). Immobilization of arsenite and ferric iron by Acidithiobacillus ferrooxidans and its relevance to acid mine drainage. Applied and Environmental Microbiology, 69(10), 6165-6173.

Fan, H., Su, C., Wang, Y., Yao, J., Zhao, K., \& Wang, G. (2008). Sedimentary arsenite-oxidizing and arsenate-reducing bacteria associated with high arsenic groundwater from Shanyin, Northwestern China. Journal of Applied Microbiology, 105(2), 529-539.

Fantauzzi, M., Licheri, C., Atzei, D., Loi, G., Elsener, B., Rossi, G., \& Rossi, A. (2011). Arsenopyrite and pyrite bioleaching: Evidence from XPS, XRD and ICP techniques. Analytical and Bioanalytical Chemistry, 401(7), 2237-2248.

Fauser, P., Sanderson, H., Hedegaard, R. V., Sloth, J. J., Larsen, M. M., Krongaard, T., Bossi, R., \& Larsen, J. B. (2013). Occurrence and sorption properties of arsenicals in marine sediments. Environmental Monitoring and Assessment, 185(6), 4679-4691.

Fendorf, S., Michael, H. A., \& van Geen, A. (2010a). Spatial and temporal variations of groundwater arsenic in South and Southeast Asia. Science, 328(5982), 1123-1127.

Fendorf, S., Nico, P. S., Kocar, B. D., Masue, Y. \& Tufano, K. J. (2010b). Arsenic chemistry in soils and sediments. http:// www.escholarship.org/uc/item/9jt907xz.

Flemming, H. C., \& Wingender, J. (2010). The biofilm matrix. Nature Reviews Microbiology, 8(9), 623-633.

Frey, B., Rieder, S. R., Brunner, I., Plotze, M., Koetzsch, S., Lapanje, A., Brandl, H., \& Furrer, G. (2010). Weatheringassociated bacteria from the Damma glacier forefield: Physiological capabilities and impact on granite dissolution. Applied and Environmental Microbiology, 76(14), 4788-4796.

Frohne, T., Rinklebe, J., Diaz-Bone, R. A., \& Du Laing, G. (2011). Controlled variation of redox conditions in a floodplain soil: Impact on metal mobilization and biomethylation of arsenic and antimony. Geoderma, 160(3-4), 414-424.

Gadd, G. M. (2004). Microbial influence on metal mobility and application for bioremediation. Geoderma, 122(2-4), 109-119.

Gadd, G. M. (2009). Biosorption: Critical review of scientific rationale, environmental importance and significance for pollution treatment. Journal of Chemical Technology and Biotechnology, 84(1), 13-28.

Gibney, B. P., \& Nusslein, K. (2007). Arsenic sequestration by nitrate respiring microbial communities in urban lake sediments. Chemosphere, 70(2), 329-336.

Gihring, T. M., Druschel, G. K., McCleskey, R. B., Hamers, R. J., \& Banfield, J. F. (2001). Rapid arsenite oxidation by Thermus aquaticus and Thermus thermophilus: Field and laboratory investigations. Environmental Science \& Technology, 35(19), 3857-3862.

Giri, A. K., Patel, R. K., Mahapatra, S. S., \& Mishra, P. C. (2013). Biosorption of arsenic (III) from aqueous solution by living cells of Bacillus cereus. Environmental Science and Pollution Research, 20(3), 1281-1291.

Hasegawa, H., Rahman, M. A., Matsuda, T., Kitahara, T., Maki, T., \& Ueda, K. (2009). Effect of eutrophication on the distribution of arsenic species in eutrophic and mesotrophic lakes. Science of the Total Environment, 407(4), 1418-1425.

Herbel, M., \& Fendorf, S. (2006). Biogeochemical processes controlling the speciation and transport of arsenic within iron coated sands. Chemical Geology, 228(1-3), 16-32.

Hippler, J., Zdrenka, R., Reichel, R. A. D., Weber, D. G., Rozynek, P., Johnen, G., Dopp, E., \& Hirner, A. V. (2011). Intracellular, time-resolved speciation and quantification of arsenic compounds in human urothelial and hepatoma cells. Journal of Analytical Atomic Spectrometry, 26(12), 2396-2403.

Hitchcock, A. P., Obst, M., Wang, J., Lu, Y. S., \& Tyliszczak, T. (2012). Advances in the detection of As in environmental 
samples using low energy X-ray fluorescence in a scanning transmission X-ray microscope: Arsenic immobilization by an $\mathrm{Fe}(\mathrm{II})$-oxidizing freshwater bacteria. Environmental Science \& Technology, 46(5), 2821-2829.

Hohmann, C., Winkler, E., Morin, G., \& Kappler, A. (2010). Anaerobic Fe(II)-oxidizing bacteria show As resistance and immobilize As during Fe(III) mineral precipitation. Environmental Science \& Technology, 44(1), 94-101.

Hohmann, C., Morin, G., Ona-Nguema, G., Guigner, J. M., Brown, G. E., \& Kappler, A. (2011). Molecular-level modes of As binding to $\mathrm{Fe}(\mathrm{III})$ (oxyhydr)oxides precipitated by the anaerobic nitrate-reducing $\mathrm{Fe}(\mathrm{II})$-oxidizing Acidovorax $s p$ strain BoFeN1. Geochimica et Cosmochimica Acta, 75(17), 4699-4712.

Hossain, S. M., \& Anantharaman, N. (2006). Studies on bacterial growth and arsenic(III) biosorption using Bacillus subtilis. Chemical and Biochemical Engineering Quarterly, 20(2), 209-216.

Huang, J.-H., \& Kretzschmar, R. (2010). Sequential extraction method for speciation of arsenate and arsenite in mineral soils. Analytical Chemistry, 82(13), 5534-5540.

Huang, J. H., \& Matzner, E. (2006). Dynamics of organic and inorganic arsenic in the solution phase of an acidic fen in Germany. Geochimica et Cosmochimica Acta, 70(8), 20232033.

Huang, J.-H., \& Matzner, E. (2007). Biogeochemistry of organic and inorganic arsenic species in a forested catchment in Germany. Environmental Science \& Technology, 41(5), 1564-1569.

Huang, J.-H., Scherr, F., \& Matzner, E. (2007). Demethylation of dimethylarsinic acid and arsenobetaine in different organic soils. Water, Air, and Soil Pollution, 182(1-4), 31-41.

Huang, J.-H., Elzinga, E. J., Brechbuchl, Y., Voegelin, A., \& Kretzschmar, R. (2011a). Impacts of Shewanella putrefaciens strain CN-32 cells and extracellular polymeric substances on the sorption of $\mathrm{As}(\mathrm{V})$ and $\mathrm{As}(\mathrm{III})$ on $\mathrm{Fe}(\mathrm{III})-(\mathrm{Hydr})$ oxides. Environmental Science \& Technology, 45(7), 2804-2810.

Huang, J.-H., Hu, K.-N., \& Decker, B. (2011b). Organic arsenic in the soil environment: Speciation, occurrence, transformation, and adsorption behavior. Water, Air, and Soil Pollution, 219(1-4), 401-415

Huang, J.-H., Voegelin, A., Pombo, S. A., Lazzaro, A., Zeyer, J., \& Kretzschmar, R. (2011c). Influence of arsenate adsorption to ferrihydrite, goethite, and boehmite on the kinetics of arsenate reduction by Shewanella putrefaciens strain CN-32. Environmental Science \& Technology, 45(18), 7701-7709.

Huber, R., Sacher, M., Vollmann, A., Huber, H., \& Rose, D. (2000). Respiration of arsenate and selenate by hyperthermophilic archaea. Systematic and Applied Microbiology, 23(3), 305-314.

Inskeep, W. P., Macur, R. E., Harrison, G., Bostick, B. C., \& Fendorf, S. (2004). Biomineralization of As(V)-hydrous ferric oxyhydroxide in microbial mats of an acid-sulfatechloride geothermal spring, Yellowstone National Park. Geochimica et Cosmochimica Acta, 68(15), 3141-3155.

Islam, F. S., Gault, A. G., Boothman, C., Polya, D. A., Charnock, J. M., Chatterjee, D., \& Lloyd, J. R. (2004). Role of metalreducing bacteria in arsenic release from Bengal delta sediments. Nature, 430(6995), 68-71.

Islam, F. S., Pederick, R. L., Gault, A. G., Adams, L. K., Polya, D. A., Charnock, J. M., \& Lloyd, J. R. (2005). Interactions between the Fe(III)-reducing bacterium Geobacter sulfurreducens and arsenate, and capture of the metalloid by biogenic Fe(II). Applied and Environmental Microbiology, 71(12), 8642-8648.

Ito, A., Miura, J., Ishikawa, N., \& Umita, T. (2012). Biological oxidation of arsenite in synthetic groundwater using immobilised bacteria. Water Research, 46(15), 4825-4831.

Jia, Y., Huang, H., Zhong, M., Wang, F. H., Zhang, L. M., \& Zhu, Y. G. (2013). Microbial arsenic methylation in soil and rice rhizosphere. Environmental Science \& Technology, 47(7), 3141-3148.

Jiang, S., Lee, J.-H., Kim, D., Kanaly, R. A., Kim, M.-G., \& Hur, H.-G. (2013). Differential arsenic mobilization from Asbearing ferrihydrite by iron-respiring Shewanella strains with different arsenic-reducing activities. Environmental Science \& Technology, 47(15), 8616-8623.

Jones, C. A., Langner, H. W., Anderson, K., McDermott, T. R., \& Inskeep, W. P. (2000). Rates of microbially mediated arsenate reduction and solubilization. Soil Science Society of America Journal, 64(2), 600-608.

Joshi, D. N., Flora, S. J. S., \& Kalia, K. (2009). Bacillus sp strain DJ-1, potent arsenic hypertolerant bacterium isolated from the industrial effluent of India. Journal of Hazardous Materials, 166(2-3), 1500-1505.

Khokiattiwong, S., Goessler, W., Pedersen, S. N., Cox, R., \& Francesconi, K. A. (2001). Dimethylarsinoylacetate from microbial demethylation of arsenobetaine in seawater. Applied Organometallic Chemistry, 15(6), 481-489.

Kim, H. C., Lee, C. G., Park, J. A., \& Kim, S. B. (2010). Arsenic removal from water using iron-impregnated granular activated carbon in the presence of bacteria. Journal of Environmental Science and Health Part A-Toxic/Hazardous Substances \& Environmental Engineering, 45(2), 177-182.

Kleinert, S., Muehe, E. M., Posth, N. R., Dippon, U., Daus, B., \& Kappler, A. (2011). Biogenic Fe(III) minerals lower the efficiency of iron-mineral-based commercial filter systems for arsenic removal. Environmental Science \& Technology, 45(17), 7533-7541.

Kocar, B. D., Herbel, M. J., Tufano, K. J., \& Fendorf, S. (2006). Contrasting effects of dissimilatory iron(III) and arsenic(V) reduction on arsenic retention and transport. Environmental Science \& Technology, 40(21), 6715-6721.

Kocar, B. D., Borch, T., \& Fendorf, S. (2010). Arsenic repartitioning during biogenic sulfidization and transformation of ferrihydrite. Geochimica et Cosmochimica Acta, 74(3), 980-994.

Kostal, J., Yang, R., Wu, C. H., Mulchandani, A., \& Chen, W. (2004). Enhanced arsenic accumulation in engineered bacterial cells expressing ArsR. Applied and Environmental Microbiology, 70(8), 4582-4587.

Kruger, M. C., Bertin, P. N., Heipieper, H. J., \& Arsene-Ploetze, F. (2013). Bacterial metabolism of environmental arsenicmechanisms and biotechnological applications. Applied Microbiology and Biotechnology, 97(9), 3827-3841.

Kuehnelt, D., \& Goessler, W. (2003). Organoarsenic compounds in the terrestrial environment. In P. J. Craig (Ed.), Organometallic compounds in the environment (pp. 223275). Heidelberg: Wiley.

Labrenz, M., Druschel, G. K., Thomsen-Ebert, T., Gilbert, B., Welch, S. A., Kemner, K. M., Logan, G. A., Summons, R. E., De Stasio, G., Bond, P. L., Lai, B., Kelly, S. D., \& 
Banfield, J. F. (2000). Formation of sphalerite ( $\mathrm{ZnS})$ deposits in natural biofilms of sulfate-reducing bacteria. Science, 290(5497), 1744-1747.

Lafferty, B. J., \& Loeppert, R. H. (2005). Methyl arsenic adsorption and desorption behavior on iron oxides. Environmental Science \& Technology, 39(7), 2120-2127.

Langner, H. W., \& Inskeep, W. P. (2000). Microbial reduction of arsenate in the presence of ferrihydrite. Environmental Science \& Technology, 34(15), 3131-3136.

Lee, J. H., Kim, M. G., Yoo, B. Y., Myung, N. V., Maeng, J. S., Lee, T., Dohnalkova, A. C., Fredrickson, J. K., Sadowsky, M. J., \& Hur, H. G. (2007). Biogenic formation of photoactive arsenic-sulfide nanotubes by Shewanella sp strain HN-41. Proceedings of the National Academy of Sciences of the United States of America, 104(51), 20410-20415.

Lehr, C. R., Polishchuk, E., Radoja, U., \& Cullen, W. R. (2003). Demethylation of methylarsenic species by Mycobacterium neoaurum. Applied Organometallic Chemistry, 17(11), 831-834.

Liao, S. J., Zhou, J. X., Wang, H., Chen, X., Wang, H. F., \& Wang, G. J. (2013). Arsenite oxidation using biogenic manganese oxides produced by a deep-sea manganese-oxidizing bacterium, Marinobacter sp MnI7-9. Geomicrobiology Journal, $30(2), 150-159$.

Liu, Q., Guo, H. M., Li, Y., \& Xiang, H. (2013a). Acclimation of arsenic-resistant $\mathrm{Fe}(\mathrm{II})$-oxidizing bacteria in aqueous environment. International Biodeterioration \& Biodegradation, 76, 86-91.

Liu, S., Hou, Y. W., \& Sun, G. X. (2013b). Synergistic degradation of pyrene and volatilization of arsenic by cocultures of bacteria and a fungus. Frontiers of Environmental Science \& Engineering, 7(2), 191-199.

Lloyd, J. R., \& Oremland, R. S. (2006). Microbial transformations of arsenic in the environment: From soda lakes to aquifers. Elements, 2(2), 85-90.

Lovley, D. R., Coates, J. D., BluntHarris, E. L., Phillips, E. J. P., \& Woodward, J. C. (1996). Humic substances as electron acceptors for microbial respiration. Nature, 382(6590), 445-448.

Lovley, D. R., Holmes, D. E. \& Nevin, K. P. (2004). Dissimilatory $\mathrm{Fe}(\mathrm{III})$ and $\mathrm{Mn}(\mathrm{IV})$ reduction. Advances in Microbial Physiology, Vol. 49 (pp. 219-286). London: Academic

Ma, Y. Q., \& Lin, C. X. (2012). Arsenate immobilization associated with microbial oxidation of ferrous ion in complex acid sulfate water. Journal of Hazardous Materials, 217, 238-245.

Macy, J. M., Santini, J. M., Pauling, B. V., O’Neill, A. H., \& Sly, L. I. (2000). Two new arsenate/sulfate-reducing bacteria: mechanisms of arsenate reduction. Archives of Microbiology, 173(1), 49-57.

Maeda, S., Ohki, A., Miyahara, K., Takeshita, T., \& Higashi, S. (1990). Growth-characteristics and arsenic metabolism of 2 species of arsenic-tolerant bacteria. Applied Organometallic Chemistry, 4(3), 245-250.

Maeda, S., Ohki, A., Miyahara, K., Naka, K., \& Higashi, S. (1992). Metabolism of methylated arsenic compounds by arsenic-resistant bacteria (Klebsiella-oxytoca and Xanthomonas sp). Applied Organometallic Chemistry, 6(4), 415-420.

Mailloux, B. J., Alexandrova, E., Keimowitz, A. R., Wovkulich, K., Freyer, G. A., Herron, M., Stolz, J. F., Kenna, T. C., Pichler, T., Polizzotto, M. L., Dong, H. L., Bishop, M., \&
Knappett, P. S. K. (2009). Microbial mineral weathering for nutrient acquisition releases arsenic. Applied and Environmental Microbiology, 75(8), 2558-2565.

Malasarn, D., Saltikov, W., Campbell, K. M., Santini, J. M., Hering, J. G., \& Newman, D. K. (2004). arrA is a reliable marker for As(V) respiration. Science, 306(5695), 455-455.

Malasarn, D., Keeffe, J. R., \& Newman, D. K. (2008). Characterization of the arsenate respiratory reductase from Shewanella sp strain ANA-3. Journal of Bacteriology, 190(1), 135-142.

Mandal, B. K., \& Suzuki, K. T. (2002). Arsenic round the world: A review. Talanta, 58(1), 201-235.

Marquez, M. A., Ospina, J. D., \& Morales, A. L. (2012). New insights about the bacterial oxidation of arsenopyrite: A mineralogical scope. Minerals Engineering, 39, 248-254.

Martinez-Villegas, N., Briones-Gallardo, R., Ramos-Leal, J. A., Avalos-Borja, M., Castanon-Sandoval, A. D., Razo-Flores, E., \& Villalobos, M. (2013). Arsenic mobility controlled by solid calcium arsenates: A case study in Mexico showcasing a potentially widespread environmental problem. Environmental Pollution, 176, 114-122.

Masue-Slowey, Y., Loeppert, R. H., \& Fendorf, S. (2011). Alteration of ferrihydrite reductive dissolution and transformation by adsorbed As and structural Al: Implications for As retention. Geochimica et Cosmochimica Acta, 75(3), 870-886.

Matlakowska, R., Drewniak, L., \& Sklodowska, A. (2008). Arsenic-hypertolerant Pseudomonads isolated from ancient gold and copper-bearing black shale deposits. Geomicrobiology Journal, 25(7-8), 357-362.

McBride, B. C., \& Wolfe, R. S. (1971). Biosynthesis of dimethylarsine by methanobacterium. Biochemistry, 10, $4312-4317$.

McKnight-Whitford, A., Chen, B. W., Naranmandura, H., Zhu, C., \& Le, X. C. (2010). New method and detection of high concentrations of monomethylarsonous acid detected in contaminated groundwater. Environmental Science \& Technology, 44(15), 5875-5880.

McNeill, L. S., \& Edwards, M. (1997). Arsenic removal during precipitative softening. Journal of Environmental Engineering-Asce, 123(5), 453-460.

Meng, X. G., Jing, C. Y. \& Korfiatis, G. P. (2003). A review of redox transformation of arsenic in aquatic environments. In Y. Cai \& O. C. Braids (Eds.), Biogeochemistry of Environmentally Important Trace Elements, Vol. 835 (pp. 70-83). Washington, DC: ACS Publications

Mestrot, A., Merle, J. K., Broglia, A., Feldmann, J., \& Krupp, E. M. (2011). Atmospheric stability of arsine and methylarsines. Environmental Science \& Technology, 45(9), 4010-4015.

Mestrot, A., Planer-Friedrich, B., \& Feldmann, J. (2013). Biovolatilisation: A poorly studied pathway of the arsenic biogeochemical cycle. Environmental Science: Processes \& Impacts, 15(9), 1639-1651.

Meyer, J., Michalke, K., Kouril, T., \& Hensel, R. (2008). Volatilisation of metals and metalloids: An inherent feature of methanoarchaea? Systematic and Applied Microbiology, 31(2), 81-87.

Meyer-Dombard, D. R., Amend, J. P., \& Osburn, M. R. (2013). Microbial diversity and potential for arsenic and iron biogeochemical cycling at an arsenic rich, shallow-sea hydrothermal vent (Tutum Bay, Papua New Guinea). Chemical Geology, $348,37-47$. 
Michalke, K., Wickenheiser, E. B., Mehring, M., Hirner, A. V., \& Hensel, R. (2000). Production of volatile derivatives of metal(loid)s by microflora involved in anaerobic digestion of sewage sludge. Applied and Environmental Microbiology, 66(7), 2791-2796.

Millward, G. E., Kitts, H. J., Comber, S. D. W., Ebdon, L., \& Howard, A. G. (1996). Methylated arsenic in the southern North Sea. Estuarine, Coastal and Shelf Science, 43(1), 1-18.

Miyatake, M., \& Hayashi, S. (2011). Characteristics of arsenic removal by Bacillus cereus Strain W2. Resources Processing, 58(3), 101-107.

Mukai, H., Ambe, Y., Muku, T., Takeshita, K., \& Fukuma, T. (1986). Seasonal-variation of methylarsenic compounds in airborne particulate matter. Nature, 324(6094), 239-241.

Mukhopadhyay, R., Rosen, B. P., Pung, L. T., \& Silver, S. (2002). Microbial arsenic: From geocycles to genes and enzymes. FEMS Microbiology Reviews, 26(3), 311-325.

Nair, A., Juwarkar, A. A., \& Singh, S. K. (2007). Production and characterization of siderophores and its application in arsenic removal from contaminated soil. Water, Air, and Soil Pollution, 180(1-4), 199-212.

Newman, D. K., Beveridge, T. J., \& Morel, F. M. M. (1997a). Precipitation of arsenic trisulfide by Desulfotomaculum auripigmentum. Applied and Environmental Microbiology, 63(5), 2022-2028.

Newman, D. K., Kennedy, E. K., Coates, J. D., Ahmann, D., Ellis, D. J., Lovley, D. R., \& Morel, F. M. M. (1997b). Dissimilatory arsenate and sulfate reduction in Desulfotomaculum auripigmentum sp. nov. Archives of Microbiology, 168(5), 380-388.

Newman, D. K., Ahmann, D., \& Morel, F. M. M. (1998). A brief review of microbial arsenate respiration. Geomicrobiology Journal, 15(4), 255-268.

Nordstrom, D. K. (2002). Public health-Worldwide occurrences of arsenic in ground water. Science, 296(5576), 2143-2145.

O’Day, P. A., Vlassopoulos, D., Root, R., \& Rivera, N. (2004). The influence of sulfur and iron on dissolved arsenic concentrations in the shallow subsurface under changing redox conditions. Proceedings of the National Academy of Sciences of the United States of America, 101(38), 13703-13708.

Ohtsuka, T., Yamaguchi, N., Makino, T., Sakurai, K., Kimura, K., Kudo, K., Homma, E., Dong, D. T., \& Amachi, S. (2013). Arsenic dissolution from Japanese paddy soil by a dissimilatory arsenate-reducing bacterium Geobacter sp OR-1. Environmental Science \& Technology, 47(12), 6263-6271.

Omoregie, E. O., Couture, R.-M., Van Cappellen, P., Corkhill, C. L., Charnock, J. M., Polya, D. A., Vaughan, D., Vanbroekhoven, K., \& Lloyd, J. R. (2013). Arsenic bioremediation by biogenic iron oxides and sulfides. Applied and Environmental Microbiology, 79(14), 4325-4335.

Oremland, R. S., \& Stolz, J. F. (2003). The ecology of arsenic. Science, 300(5621), 939-944.

Ozaki, T., Wang, X. X., \& Ohnuki, T. (2013). Manganese and arsenic oxidation performance of bacterium-yunotaki 86 (by86) from Hokkaido, Japan, and the bacterium's phylogeny. Geomicrobiology Journal, 30(7), 559-565.

Paez-Espino, D., Tamames, J., de Lorenzo, V., \& Canovas, D. (2009). Microbial responses to environmental arsenic. Biometals, 22(1), 117-130.

Palmer, N. E., \& von Wandruszka, R. (2010). Humic acids as reducing agents: The involvement of quinoid moieties in arsenate reduction. Environmental Science and Pollution Research, 17(7), 1362-1370.

Parke, E. C. (2013). What could arsenic bacteria teach us about life? Biology \& Philosophy, 28(2), 205-218.

Pedersen, H. D., Postma, D., \& Jakobsen, R. (2006). Release of arsenic associated with the reduction and transformation of iron oxides. Geochimica et Cosmochimica Acta, 70(16), 4116-4129.

Petrick, J. S., Ayala-Fierro, F., Cullen, W. R., Carter, D. E., \& Aposhian, H. V. (2000). Monomethylarsonous acid (MMA(III)) is more toxic than arsenite in Chang human hepatocytes. Toxicology and Applied Pharmacology, 163(2), 203-207.

Poli, A., Di Donato, P., Abbamondi, G. R. \& Nicolaus, B. (2011). Synthesis, production, and biotechnological applications of exopolysaccharides and polyhydroxyalkanoates by archaea. Archaea-an International Microbiological Journal, 2011, 693253.

Prasad, K. S., Srivastava, P., Subramanian, V., \& Paul, J. (2011). Biosorption of As(III) ion on Rhodococcus sp WB-12: Biomass characterization and kinetic studies. Separation Science and Technology, 46(16), 2517-2525.

Qin, J., Rosen, B. P., Zhang, Y., Wang, G. J., Franke, S., \& Rensing, C. (2006). Arsenic detoxification and evolution of trimethylarsine gas by a microbial arsenite Sadenosylmethionine methyltransferase. Proceedings of the National Academy of Sciences of the United States of America, 103(7), 2075-2080.

Raven, K. P., Jain, A., \& Loeppert, R. H. (1998). Arsenite and arsenate adsorption on ferrihydrite: Kinetics, equilibrium, and adsorption envelopes. Environmental Science \& Technology, 32(3), 344-349.

Robins, R. G. (1981). The solubility of metal arsenates. Metallurgical Transactions B-Process Metallurgy, 12(1), 103-109.

Saalfield, S. L., \& Bostick, B. C. (2009). Changes in iron, sulfur, and arsenic speciation associated with bacterial sulfate reduction in ferrihydrite-rich systems. Environmental Science \& Technology, 43(23), 8787-8793.

Senn, D. B., \& Hemond, H. F. (2002). Nitrate controls on iron and arsenic in an urban lake. Science, 296(5577), 2373-2376.

Shah, D., Shen, M. W. Y., Chen, W., \& Da Silva, N. A. (2010). Enhanced arsenic accumulation in Saccharomyces cerevisiae overexpressing transporters Fps1p or Hxt7p. Journal of Biotechnology, 150(1), 101-107.

Shariatpanahi, M., Anderson, A. C., Abdelghani, A. A., Englande, A. J., Hughes, J., \& Wilkinson, R. F. (1981). Biotransformation of the pesticide sodium arsenate. Journal of Environmental Science and Health Part B-Pesticides Food Contaminants and Agricultural Wastes, 16(1), 35-47.

Shariatpanahi, M., Anderson, A. C., Abdelghani, A. A., \& Englande, A. J. (1983). Microbial metabolism of an organic arsenical herbicide. In T. A. Oxley \& S. Barry (Eds.), Biodeterioration (pp. 268-277). Chichester: Wiley.

Sierra-Alvarez, R., Yenal, U., Field, J. A., Kopplin, M., Gandolfi, A. J., \& Garbarino, J. R. (2006). Anaerobic biotransformation of organoarsenical pesticides monomethylarsonic acid and dimethylarsinic acid. Journal of Agricultural and Food Chemistry, 54(11), 3959-3966.

Silver, S., \& Phung, L. T. (2005). Genes and enzymes involved in bacterial oxidation and reduction of inorganic arsenic. Applied and Environmental Microbiology, 71(2), 599-608. 
Singh, S., Kang, S. H., Lee, W., Mulchandani, A., \& Chen, W. (2010). Systematic engineering of phytochelatin synthesis and arsenic transport for enhanced arsenic accumulation in E-coli. Biotechnology and Bioengineering, 105(4), 780-785.

Slyemi, D., \& Bonnefoy, V. (2012). How prokaryotes deal with arsenic. Environmental Microbiology Reports, 4(6), 571-586.

Smeaton, C. M., Walshe, G. E., Smith, A. M. L., HudsonEdwards, K. A., Dubbin, W. E., Wright, K., Beale, A. M., Fryer, B. J., \& Weisener, C. G. (2012). Simultaneous release of $\mathrm{Fe}$ and $\mathrm{As}$ during the reductive dissolution of $\mathrm{Pb}-\mathrm{As}$ jarosite by Shewanella putrefaciens $\mathrm{CN} 32$. Environmental Science \& Technology, 46(23), 12823-12831.

Smedley, P. L., \& Kinniburgh, D. G. (2002). A review of the source, behaviour and distribution of arsenic in natural waters. Applied Geochemistry, 17(5), 517-568.

Srivastava, P. K., Vaish, A., Dwivedi, S., Chakrabarty, D., Singh, N., \& Tripathi, R. D. (2011). Biological removal of arsenic pollution by soil fungi. Science of the Total Environment, 409(12), 2430-2442.

Stolz, J. F., \& Oremland, R. S. (1999). Bacterial respiration of arsenic and selenium. FEMS Microbiology Reviews, 23(5), 615-627.

Stolz, J. F., Basu, P., \& Oremland, R. S. (2002). Microbial transformation of elements: The case of arsenic and selenium. International Microbiology, 5, 201-207.

Stolz, J. E., Basu, P., Santini, J. M., \& Oremland, R. S. (2006). Arsenic and selenium in microbial metabolism. Annual Review of Microbiology, 60, 107-130.

Su, S. M., Zeng, X. B., Li, L. F., Duan, R., Bai, L. Y., Li, A. G., Wang, J., \& Jiang, S. (2012). Arsenate reduction and methylation in the cells of Trichoderma asperellum SM-12 F1, Penicillium janthinellum SM-12 F4, and Fusarium oxysporum CZ-8 F1 investigated with X-ray absorption near edge structure. Journal of Hazardous Materials, 243, 364-367.

Sun, W. (2008). Microbial oxidation of arsenite in anoxic environments: Impacts on arsenic mobility. Tuczon: The University of Arizona.

Sun, W. J., Sierra-Alvarez, R., Milner, L., Oremland, R., \& Field, J. A. (2009). Arsenite and ferrous iron oxidation linked to chemolithotrophic denitrification for the immobilization of arsenic in anoxic environments. Environmental Science \& Technology, 43(17), 6585-6591.

Tadanier, C. J., Schreiber, M. E., \& Roller, J. W. (2005). Arsenic mobilization through microbially mediated deflocculation of ferrihydrite. Environmental Science \& Technology, 39(9), 3061-3068.

Taillefert, M., Beckler, J. S., Carey, E., Burns, J. L., Fennessey, C. M., \& DiChristina, T. J. (2007). Shewanella putrefaciens produces an $\mathrm{Fe}(\mathrm{III})$-solubilizing organic ligand during anaerobic respiration on insoluble Fe(III) oxides. Journal of Inorganic Biochemistry, 101(11-12), 1760-1767.

Takeuchi, M., Kawahata, H., Gupta, L. P., Kita, N., Morishita, Y., Ono, Y., \& Komai, T. (2007). Arsenic resistance and removal by marine and non-marine bacteria. Journal of Biotechnology, 127(3), 434 442.

Tamaki, S., \& Frankenberger, W. T. (1992). Environmental biochemistry of arsenic. Reviews of Environmental Contamination and Toxicology, 124, 79-110.

Tani, Y., Miyata, N., Ohashi, M., Ohnuki, T., Seyama, H., Iwahori, K., \& Soma, M. (2004). Interaction of inorganic arsenic with biogenic manganese oxide produced by a Mn-oxidizing fungus, strain KR21-2. Environmental Science \& Technology, 38(24), 6618-6624.

Thanabalasingam, P., \& Pickering, W. F. (1986). Arsenic sorption by humic acids. Environmental Pollution Series B-Chemical and Physical, 12(3), 233-246.

Tomczyk-Żak, K., Kaczanowski, S., Drewniak, Ł., Dmoch, Ł., Sklodowska, A., \& Zielenkiewicz, U. (2013). Bacteria diversity and arsenic mobilization in rock biofilm from an ancient gold and arsenic mine. Science of the Total Environment, 461-462, 330-340.

Toner, B., Manceau, A., Webb, S. M., \& Sposito, G. (2006). Zinc sorption to biogenic hexagonal-birnessite particles within a hydrated bacterial biofilm. Geochimica et Cosmochimica Acta, 70(1), 27-43.

Torsvik, V., Ovreas, L., \& Thingstad, T. F. (2002). Prokaryotic diversity-Magnitude, dynamics, and controlling factors. Science, 296(5570), 1064-1066.

Tsai, S. L., Singh, S., \& Chen, W. (2009). Arsenic metabolism by microbes in nature and the impact on arsenic remediation. Current Opinion in Biotechnology, 20(6), 659-667.

Tufano, K. J., \& Fendorf, S. (2008). Confounding impacts of iron reduction on arsenic retention. Environmental Science \& Technology, 42(13), 4777-4783.

Tufano, K. J., Reyes, C., Saltikov, C. W., \& Fendorf, S. (2008). Reductive processes controlling arsenic retention: revealing the relative importance of iron and arsenic reduction. Environmental Science \& Technology, 42(22), 8283-8289.

Turpeinen, R., Pantsar-Kallio, M., Haggblom, M., \& Kairesalo, T. (1999). Influence of microbes on the mobilization, toxicity and biomethylation of arsenic in soil. Science of the Total Environment, 236(1-3), 173-180.

Vahidnia, A., Van der Voet, G. B., \& de Wolf, F. A. (2007). Arsenic neurotoxicity-A review. Human \& Experimental Toxicology, 26(10), 823-832.

van Hullebusch, E. D., Zandvoort, M. H., \& Lens, P. N. L. (2003). Metal immobilisation by biofilms: Mechanisms and analytical tools. Reviews in Environmental Science and Biotechnology, 2, 9-33.

Wang, S. L., \& Zhao, X. Y. (2009). On the potential of biological treatment for arsenic contaminated soils and groundwater. Journal of Environmental Management, 90(8), 2367-2376.

Weng, L. P., Van Riemsdijk, W. H., \& Hiemstra, T. (2009). Effects of fulvic and humic acids on arsenate adsorption to goethite: Experiments and modeling. Environmental Science \& Technology, 43(19), 7198-7204.

Williams, G. P., Gnanadesigan, M., \& Ravikumar, S. (2013). Biosorption and bio-kinetic properties of solar saltern Halobacterial strains for managing $\mathrm{Zn}^{2+}, \mathrm{As}^{2+}$ and $\mathrm{Cd}^{2+}$ Metals. Geomicrobiology Journal, 30(6), 497-500.

Wolfe-Simon, F., Blum, J. S., Kulp, T. R., Gordon, G. W., Hoeft, S. E., Pett-Ridge, J., Stolz, J. F., Webb, S. M., Weber, P. K., Davies, P. C. W., Anbar, A. D., \& Oremland, R. S. (2011). A bacterium that can grow by using arsenic instead of phosphorus. Science, 332(6034), 1163-1166.

$\mathrm{Wu}$, J. (2005). A comparative study of arsenic methylation in a plant, yeast and bacterium. Wollongong: The University of Wollongong.

Wuerfel, O., Thomas, F., Schulte, M. S., Hensel, R., \& Diaz-Bone, R. A. (2012). Mechanism of multi-metal(loid) methylation and hydride generation by methylcobalamin and 
cob(I)alamin: A side reaction of methanogenesis. Applied Organometallic Chemistry, 26(2), 94-101.

Xie, Z. M., Luo, Y., Wang, Y. X., Xie, X. J., \& Su, C. L. (2013). Arsenic resistance and bioaccumulation of an indigenous bacterium isolated from aquifer sediments of Datong Basin, Northern China. Geomicrobiology Journal, 30(6), 549-556.

Yamamura, S., Watanabe, M., Kanzaki, M., Soda, S., \& Ike, M. (2008). Removal of arsenic from contaminated soils by microbial reduction of arsenate and quinone. Environmental Science \& Technology, 42(16), 6154-6159.

Yan, L., Yin, H. H., Zhang, S., Leng, F. F., Nan, W. B., \& Li, H. Y. (2010). Biosorption of inorganic and organic arsenic from aqueous solution by Acidithiobacillus ferrooxidans BY-3. Journal of Hazardous Materials, 178(1-3), 209-217.

Yang, S. I., Lawrence, J. R., Swerhone, G. D. W., \& Pickering, I. J. (2011). Biotransformation of selenium and arsenic in multispecies biofilm. Environmental Chemistry, 8(6), 543-551.

Yang, T., Chen, M. L., Liu, L. H., Wang, J. H., \& Dasgupta, P. K. (2012). Iron(III) modification of Bacillus subtilis membranes provides record sorption capacity for arsenic and endows unusual selectivity for As(V). Environmental Science \& Technology, 46(4), 2251-2256.

Ying, S. C., Kocar, B. D., Griffis, S. D., \& Fendorf, S. (2011). Competitive microbially and $\mathrm{Mn}$ oxide mediated redox processes controlling arsenic speciation and partitioning. Environmental Science \& Technology, 45(13), 5572-5579.
Ying, S. C., Kocar, B. D., \& Fendorf, S. (2012). Oxidation and competitive retention of arsenic between iron- and manganese oxides. Geochimica et Cosmochimica Acta, 96, 294-303.

Ying, S. C., Masue-Slowey, Y., Kocar, B. D., Griffis, S. D., Webb, S., Marcus, M. A., Francis, C. A., \& Fendorf, S. (2013). Distributed microbially- and chemically-mediated redox processes controlling arsenic dynamics within $\mathrm{Mn}-/ \mathrm{Fe}-$ oxide constructed aggregates. Geochimica et Cosmochimica Acta, 104, 29-41.

Yoshinaga, M., Cai, Y., \& Rosen, B. P. (2011). Demethylation of methylarsonic acid by a microbial community. Environmental Microbiology, 13(5), 1205-1215.

Yuan, C. G., Lu, X. F., Qin, J., Rosen, B. P., \& Le, X. C. (2008). Volatile arsenic species released from Escherichia coli expressing the AsIII S-adenosylmethionine methyltransferase gene. Environmental Science \& Technology, 42(9), 3201-3206.

Zhang, J. H., Zhang, X., Ni, Y. Q., Yang, X. J., \& Li, H. Y. (2007). Bioleaching of arsenic from medicinal realgar by pure and mixed cultures. Process Biochemistry, 42(9), 1265-1271.

Zheng, R. L., Sun, G. X., \& Zhu, Y. G. (2013). Effects of microbial processes on the fate of arsenic in paddy soil. Chinese Science Bulletin, 58(2), 186-193.

Zobrist, J., Dowdle, P. R., Davis, J. A., \& Oremland, R. S. (2000). Mobilization of arsenite by dissimilatory reduction of adsorbed arsenate. Environmental Science \& Technology, 34(22), 4747-4753. 